\title{
Biosorption of nickel and cadmium in the presence of diethylketone by a Streptococcus equisimilis biofilm supported on vermiculite
}

\author{
Filomena Costa*, Teresa Tavares \\ Centre of Biological Engineering, University of Minho, Campus de Gualtar, 4710-057, Braga, Portugal
}

\section{A R T I C L E I N F O}

\section{Article history:}

Received 1 June 2016

Received in revised form

12 August 2016

Accepted 14 August 2016

\section{Keywords:}

Cadmium

Diethylketone

Nickel

Sorption

Streptococcus equisimilis

Vermiculite

\begin{abstract}
A B S T R A C T
A Streptococcus equisimilis biofilm supported on clays was used to decontaminate aqueous solutions containing diethylketone (DEK), nickel and/or cadmium, in a batch mode. The interaction between the sorbent matrices and the different sorbates, individually and in binary combinations, was evaluated. It was demonstrated that the growth of $S$. equisimilis is negatively affected by concentrations higher than $80 \mathrm{mg} \mathrm{l}^{-1}$ of $\mathrm{Ni}$ and $5 \mathrm{mg} \mathrm{l}^{-1}$ of Cd. DEK and Cd uptakes are positively correlated with the mass of vermiculite without biofilm, as observed in singular sorbate experiments. The same trend is observed for sorption percentages, reporting to the initial solution concentrations, as values higher than $90 \%$ were achieved for both pollutants. Although Ni uptake decreases as the mass of vermiculite increases, the percentage of sorbed $\mathrm{Ni}$ increased, reaching a maximum value of $100 \%$. It was demonstrated that $\mathrm{Ni}$ and DEK, when mixed, present higher sorption values, suggesting a synergetic interaction between these two pollutants, whereas when DEK and Cd are mixed, the sorption of DEK decreases significantly, revealing a negative effect of $\mathrm{Cd}$ over the retention of DEK. It was also observable that for sorbent mass higher than $0.085 \mathrm{~g}$ the simultaneous uptake of DEK and $\mathrm{Ni}$ by the biofilm supported on vermiculite decreases, but the sorption percentage tends to increase, reaching values of $100 \%$ for $40 \mathrm{~g}$ of vermiculite. As the mass of sorbent increases the sorption percentage of both sorbates, DEK and $\mathrm{Cd}$, tends to increase, reaching maximum values higher than $98 \%$. These sorption systems are effective and the use of a biofilm may be an important advantage for the treatment of aqueous solutions contaminated with specific pollutants.
\end{abstract}

(C) 2016 Elsevier Ltd. All rights reserved.

\section{Introduction}

Hazardous contamination of water and soil is among the most important current environmental problems (Montagnolli et al., 2009). The contaminants may include heavy metals, polyaromatic hydrocarbons and volatile organic compounds that are harmful to humans due to their carcinogenic, mutagenic and toxic properties, their ability to produce hazardous intermediates and to persist in the environment (Volesky, 1990; Vieira et al., 2010; Costa et al., 2012). Some of these substances are hardly degraded in nature and can easily bio-accumulate via food chain in living tissues, triggering numerous diseases and health disorders (Srivastava et al., 2006; Qin et al., 2012; Chaudhuri et al., 2014).

Several metals are currently of high concern and environmental impact (Ahmed et al., 1998; Chopra and Pathak, 2010; Kumar et al.,

\footnotetext{
* Corresponding author.

E-mail address: filomenacpcosta@ceb.uminho.pt (F. Costa).
}

2011; Merrikhpour and Jalali, 2013), as it is the case of nickel (Ni) and cadmium (Cd). Ni is well-known for its carcinogenic, embryotoxin and nephrotoxin properties and its ability to cause several types of acute and chronic health disorders (Suazo-Madrid et al., 2011). Although Cd plays no constructive role in human body, it may cause cancer and severe damage in different organs, lead to infertility (Chaudhuri et al., 2014) and affect the action of enzymes, hampering respiration, photosynthesis, transpiration and chlorosis (Ahmed et al., 1998). Cd presents high mobility in soil, high solubility in water and extreme toxicity, even at low concentration (Chaudhuri et al., 2014).

Ketones are crucial trace constituents of the earth's troposphere and their release into the atmosphere may occur through biogenic and anthropogenic processes (Lam et al., 2012; Quintelas et al., 2012). Diethylketone is a simple symmetrical dialkyl ketone that is naturally produced and released by plants, fruits (http:// pubchem.ncbi.nlm.nih.gov/, http://toxnet.nlm.nih.gov/index.html) and by several industries (paint, plastic, food and pharmaceutical industries). Diethylketone can react with $\mathrm{OH}$ radicals in the 
atmosphere and promote the formation of ozone and other components of the photochemical smog in urban areas (Lam et al., 2012). Exposure to this ketone may provoke dizziness, tachycardia, fainting and even cause coma or death in case of prolonged exposure. Stricter environmental laws were enacted in most countries in order to control, minimize and prevent pollution as well as to protect and improve the quality of the environment, (Morlett-Chávez et al., 2010; Quintelas et al., 2012; AhmadyAsbchin and Jafari, 2013).

Some of the techniques used to remove metals include chemical precipitation, reverse osmosis (Kumar et al., 2012; Qin et al., 2012; Hadi et al., 2013), ion exchange and adsorption (Vieira et al., 2010), whereas the techniques used to degrade organic solvents may comprehend thermal degradation, oxidation (Sahoo et al., 2010; Costa et al., 2012), condensation and incineration (Raghuvanshi, and Babu, 2010). Several studies demonstrated that among all these techniques, the biological adsorption processes are quite promising (Chen et al., 2000; Marseaut et al., 2004; Sar et al., 2004) and present some advantages such as low maintenance costs, high efficiency and eco-friendly character (Araújo and Teixeira, 1997; Sar et al., 1999; Çelekli and Bozkurt, 2011). Moreover, biological techniques do not generate solid wastes and do not produce nitrogen oxides, which require a secondary treatment (Raghuvanshi, and Babu, 2010; Sahoo et al., 2010; Costa et al., 2012).

The use of a joint system clay-microorganisms (Çelekli and Bozkurt, 2011; Quintelas et al., 2012) to remove pollutants from wastewater has proven its efficiency and has numerous advantages (Morlett-Chávez et al., 2010) since it combines the adsorbent characteristics of the clay: large specific surface area, excellent physical and chemical stability, high cation exchange capacity (Quintelas et al., 2012), with the microorganisms ability to degrade, fix and/or entrap pollutants from aquatic environment, a consequence of the numerous chemical groups (chitin acetamides, phosphate, amino, carboxylic groups, nucleic acids and proteins) present on the biomass surface (Yin et al., 2011; Costa et al., 2012). Sorption tests with and without biofilm aim to corroborate the added value of the biofilm to contaminated water treatment. Special attention is paid to modelling of the kinetics and of the equilibria of the retention processes for the different combinations of sorbates and sorbents. The goal of equilibria modelling is the establishment of the uptake that may be expected for the tested biosorbents which constitutes a basic evaluation of their competitiveness. These models also contribute for the establishment of the retention mechanisms, allowing the optimization of parameters to enhance water treatment. The kinetics modelling aims the identification of rate limiting steps that may be overcome by intervention in technical procedures.

The main objective of this work is the development of an environment-friendly technology for the treatment of single and binary pollutants solutions containing $\mathrm{Ni}(\mathrm{II})$ plus diethylketone or $\mathrm{Cd}(\mathrm{II})$ plus diethylketone. Although these two types of pollutants (metals and ketones) appear together in wastewater of different industries such as metal refining (Dbson and Burgess, 2007) and paint manufacturing, there are very few published works regarding the simultaneous treatment of these two types of pollutants.

\section{Materials and methods}

\subsection{Bacterial strain and chemicals}

The bacterial strain Streptococcus equisimilis was acquired from the Spanish Type Culture Collection, from the University of Valencia, with reference CECT 926. Vermiculite, purchased from SigmaAldrich, presents a BET surface area of $39 \mathrm{~m}^{2} / \mathrm{g}$, an average particle diameter of $8.45 \mathrm{~mm}$ and a porosity of $10 \%$. In the present study, vermiculite was used as sorbent as well as a support for the bacterial biofilm establishment and development. Brain Heart Infusion (Oxoid CM1135) culture medium, previously sterilized for $20 \mathrm{~min}$ at $121^{\circ} \mathrm{C}$, was used for bacteria growth. Diethylketone was purchased from Acros Organics (98\% pure) and diluted in sterilized distilled water. Individual stock solutions of $1 \mathrm{~g} \mathrm{l}^{-1}$ of nickel $\left(\mathrm{NiCl}_{2} \cdot 6 \mathrm{H}_{2} \mathrm{O}\right.$, Carlo Erba Reagents) and $1 \mathrm{~g} \mathrm{l}^{-1}$ of cadmium $\left(\mathrm{CdSO}_{4} \cdot 8 / 3 \mathrm{H}_{2} \mathrm{O}\right.$, Riedel-de-Haën) were prepared by dissolving an appropriate amount of metal in $1 \mathrm{l}$ of sterilized distilled water. The multi-element ICP quality control standard solution was purchased from CHEM Lab (QCS-03) (15E). Metal concentrations varied between $5 \mathrm{mg} \mathrm{l}^{-1}$ and $450 \mathrm{mg} \mathrm{l}^{-1}$ for $\mathrm{Ni}$ (II) and between $5 \mathrm{mg} \mathrm{l}^{-1}$ and $100 \mathrm{mg} \mathrm{l}^{-1}$ for $\mathrm{Cd}(\mathrm{II})$. The concentration of diethylketone used in all the assays was $3 \mathrm{~g} \mathrm{l}^{-1}$.

\subsection{Effect of the initial metal concentration on microbial growth}

1-L Erlenmeyer flasks containing 0.51 of sterilized Brain Heart Infusion culture medium were inoculated with a pure culture of Streptococcus equisimilis and left in an incubator for $24 \mathrm{~h}$ at $150 \mathrm{rpm}$ and $37{ }^{\circ} \mathrm{C}$. The toxicity experiments were conducted in $0.250-\mathrm{L}$ Erlenmeyer flasks containing $0.125 \mathrm{l}$ of sterilized Brain Heart Infusion culture medium and $\mathrm{Ni}(\mathrm{II})\left(5 \mathrm{mg} \mathrm{l}^{-1}\right.$ to $\left.450 \mathrm{mg} \mathrm{l}^{-1}\right)$ or Cd(II) ( $5 \mathrm{mg} \mathrm{l}^{-1}$ to $100 \mathrm{mg} \mathrm{l}^{-1}$ ). These Erlenmeyer flasks were subsequently inoculated with $10 \mathrm{ml}$ of the previous culture and incubated in an orbital shaker ( $150 \mathrm{rpm})$ at $37{ }^{\circ} \mathrm{C}$ for several hours. Samples were collected at different time intervals and centrifuged at $1300 \mathrm{rpm}$ (Eppendorf MiniSpin 9056) for $10 \mathrm{~min}$. The resuspended pellet was used to quantify the biomass concentration by optical density (OD, $620 \mathrm{~nm}$ ). The supernatant was used to quantify the concentration of metal by ICP-OES. A blank, containing culture medium and bacteria was used to assess the standard growth of Streptococcus equisimilis. The toxicity of DEK towards S. equisimilis was reported by Costa et al. (2014).

\subsection{Sorption on vermiculite - singular and binary experiments}

Singular and binary sorption experiments conducted with vermiculite acting as the only sorbent were performed and aimed to evaluate the sorption capacity of vermiculite towards diethylketone, $\mathrm{Ni}(\mathrm{II})$ and $\mathrm{Cd}(\mathrm{II})$ individually and mixed, and also to assess the interaction between the different sorbates and the sorbent. These experiments were designed to evaluate the retention efficiency of vermiculite and compare it with the retention efficiency of a biofilm supported on that very vermiculite. Diethylketone sorption experiments were performed in 1-L Erlenmeyer flasks containing $0.425 \mathrm{l}$ of diethylketone solution $\left(3 \mathrm{~g} \mathrm{l}^{-1}\right)$ and different masses of vermiculite $(0.085 \mathrm{~g}-40 \mathrm{~g})$. The Erlenmeyer flasks were placed in an orbital shaker ( $150 \mathrm{rpm})$ at $37^{\circ} \mathrm{C}$ until thermodynamic equilibrium was reached, that is when DEK concentration in the solid phase is in dynamic equilibrium with DEK concentration in the aqueous phase. Former experiments were conducted in order to determine the required time for equilibrium to be reached ( $90 \mathrm{~h}$ ). Samples of $1 \mathrm{ml}$ were collected at different time intervals and centrifuged at $13400 \mathrm{rpm}$ for $10 \mathrm{~min}$. The supernatant was analyzed by gas chromatography (GC) so that the time course of diethylketone concentration might be determined. A blank containing an aqueous solution of DEK was used to assess any eventual sorption by the Erlenmeyer flasks walls. $\mathrm{Ni}$ and $\mathrm{Cd}$ sorption assays were accomplished with 1-L Erlenmeyer flasks containing $0.425 \mathrm{l}$ of the metal solution ( $450 \mathrm{mg} \mathrm{l}^{-1}$ for $\mathrm{Ni}(\mathrm{II})$ and $100 \mathrm{mg} \mathrm{l}^{-1}$ for $\mathrm{Cd}(\mathrm{II})$ ) and different masses of vermiculite $(5 \mathrm{~g}, 7.5 \mathrm{~g}, 20 \mathrm{~g}$ and $40 \mathrm{~g})$. The Erlenmeyer flasks were kept in an incubator as before. Previous experiments indicated the required time for equilibrium to be reached (15 h for $\mathrm{Ni}(\mathrm{II})$ and $10 \mathrm{~h}$ for $\mathrm{Cd}(\mathrm{II})$ ). Samples of $1 \mathrm{ml}$ were 
periodically collected and processed. The supernatant was analyzed by ICP-OES. A blank containing an aqueous solution of metal (Ni or Cd) was used to assess any eventual sorption by the Erlenmeyer flasks walls.

The binary experiments were conducted in 1-L Erlenmeyer flasks with a working volume of 0.4251 containing $3 \mathrm{~g} \mathrm{l}^{-1}$ of diethylketone, $450 \mathrm{mg} \mathrm{l}^{-1}$ of $\mathrm{Ni}(\mathrm{II})$ or $100 \mathrm{mg} \mathrm{l}^{-1}$ of $\mathrm{Cd}(\mathrm{II})$ and different quantities of vermiculite $(5 \mathrm{~g}, 7.5 \mathrm{~g}, 20 \mathrm{~g}$ and $40 \mathrm{~g})$. The Erlenmeyer flasks were shaken as before. The required time for equilibrium to be reached ( $20 \mathrm{~h}$ for $\mathrm{Ni}(\mathrm{II})$ and DEK, $17 \mathrm{~h}$ for $\mathrm{Cd}(\mathrm{II})$ and DEK) was previously determined. Samples were collected as before. The supernatant was analyzed by GC and ICP-OES. Blanks containing an aqueous solution of metal ( $\mathrm{Ni}(\mathrm{II})$ or $\mathrm{Cd}(\mathrm{II}))$ and diethylketone were tested as before.

\subsection{Biosorption experiments}

The biosorption experiments were performed in 2-L Erlenmeyer flasks containing $0.850 \mathrm{l}$ of working volume. Each Erlenmeyer flask contained $5 \mathrm{~g}-6 \mathrm{~g}$ of Streptococcus equisimilis biomass, vermiculite $(0.085 \mathrm{~g}-40 \mathrm{~g})$, diethylketone $\left(3 \mathrm{~g} \mathrm{l}^{-1}\right)$ and $\mathrm{Ni}(\mathrm{II})\left(450 \mathrm{mg} \mathrm{l}^{-1}\right)$ or $\mathrm{Cd}(\mathrm{II})\left(100 \mathrm{mg} \mathrm{l}^{-1}\right)$. All flasks were incubated in an orbital shaker (150 rpm) at $37^{\circ} \mathrm{C}$ until equilibrium was reached. Previous experiments established the time for equilibrium to be reached: $165 \mathrm{~h}$ for DEK and $100 \mathrm{~h}$ for $\mathrm{Ni}(\mathrm{II}) ; 192.5 \mathrm{~h}$ for $7.5 \mathrm{~g}$ and $10 \mathrm{~g}$ and $309.5 \mathrm{~h}$ for the remaining masses of vermiculite, for DEK, and $100 \mathrm{~h}$ for $\mathrm{Cd}(\mathrm{II})$. Samples were collected as before. ICP-OES and GC were used to quantify the concentration of DEK and metals along the assays duration. A blank containing metal, diethylketone and vermiculite was used to isolate the influence of the biomass on the sorption process.

All experiments were performed under sterile conditions, in duplicate, with $\mathrm{pH}$ monitoring. The results represent the average of those duplicates and have relative standard deviation and relative errors inferior to $2 \%$ and $5 \%$, respectively.

\subsection{Analytical procedures}

The concentration of diethylketone in aqueous samples was measured using a GC-MS Varian 4000, equipped with a flame ionization detector (FID), with mass spectrometry (MS) and a ZBWAXplus column $(30 \mathrm{~m} \times 0.53 \mathrm{~mm} \times 1.0 \mu \mathrm{m})$. The column was initially held at a temperature $50{ }^{\circ} \mathrm{C}$, then heated at $3^{\circ} \mathrm{C} /$ minute to $100{ }^{\circ} \mathrm{C}$, held at $100{ }^{\circ} \mathrm{C}$ for $4 \mathrm{~min}$, then heated again at $40^{\circ} \mathrm{C} /$ minute to $150{ }^{\circ} \mathrm{C}$ and finally held at $150{ }^{\circ} \mathrm{C}$ for $2 \mathrm{~min}$. The temperature of injector and detector was maintained at $250{ }^{\circ} \mathrm{C}$. Nitrogen was used as the carrier gas at a flow rate of $4 \mathrm{ml} / \mathrm{min}$ and samples were injected in split mode with a split ratio of $1: 10$. Under these conditions, the retention time for diethylketone is $5.6 \mathrm{~min}$. The concentration of nickel and cadmium in aqueous samples were measured by Inductively Coupled Plasma Optical Emission Spectrometry, ICP-OES (Optima 8000, PerkinElmer). The operating conditions were as follows: RF power: $1300 \mathrm{~W}$; argon plasma flow of $8 \mathrm{l} /$ minute; auxiliary gas flow of $0.2 \mathrm{l} /$ minute; nebulizer gas flow of $0.5 \mathrm{l} /$ minute; radial plasma view, for $\mathrm{Ni}(\mathrm{II})$ and axial plasma view for $\mathrm{Cd}(\mathrm{II})$; wavelength of $221.648 \mathrm{~nm}$ for $\mathrm{Ni}(\mathrm{II})$ and $226.502 \mathrm{~nm}$ for $\mathrm{Cd}(\mathrm{II})$. All the calibration solutions were prepared from a stock solution of $\mathrm{Ni}(\mathrm{II})\left(1 \mathrm{~g} \mathrm{l}^{-1}\right)$ and $\mathrm{Cd}(\mathrm{II})\left(1 \mathrm{~g} \mathrm{l}^{-1}\right)$ as mentioned in Section 2.1. All the samples were acidified with nitric acid before being analyzed. The instrument response was periodically checked with the multi-element ICP QC standard solution (CHEM LAB) and with a blank $\left(\mathrm{HNO}_{3} 5 \%\right)$.

\subsection{Processes modelling}

Six growth kinetic models were tested using MATLAB software in order to describe the growth of the biomass, when exposed to different concentrations of $\mathrm{Ni}$ and $\mathrm{Cd}$. The tested models were Monod (Monod, 1949), Powell (Powell, 1967), Haldane (Andrews, 1968), Luong (Luong, 1987), Edwards (Edwards, 1970) and Gompertz (Zwietering et al., 1990; Fan et al., 2004; Wang and Gu, 2005). The zero order, pseudo-first order and pseudo-second order models were tested in order to understand the sorption kinetics of the three pollutants. The equilibrium of the sorption process describes the distribution of metal ions between the liquid phase and the solid sorbent phase and is usually modeled by adsorption isotherms. The adsorption isotherms tested were the Langmuir, Freundlich, Dubinin-Radushkevich (D-R) and BET models (Saravanan et al., 2009; Kishore et al., 2013).

\section{Results and discussion}

\subsection{Effect of metal on the microbial growth}

The lag phase of the biomass growth is not affected by the different $\mathrm{Ni}$ (II) concentrations ( $5 \mathrm{mg} \mathrm{l}^{-1}$ to $450 \mathrm{mg} \mathrm{l}^{-1}$ ), Fig. 1a. For concentrations lower than $100 \mathrm{mg} \mathrm{l}^{-1}$, the specific growth rate tends to increase with the increase of $\mathrm{Ni}$ (II) concentration and is higher than the reference specific growth rate, whereas for higher concentrations this rate decreases to values closer to the control value. The microbial culture requires the same time to undergo intracellular changes in an effort to adapt to a set of new environment conditions no matter the xenobiotic concentration and there is a positive stimulation by $\mathrm{Ni}(\mathrm{II})$ on the growth of the bacterium for concentrations lower than $100 \mathrm{mg} \mathrm{l}^{-1}$. The uptake and percentage of $\mathrm{Ni}(\mathrm{II})$ sorbed depend on the initial concentration of nickel (Fig. 1b). There were no significant changes (less than 10\%) in terms of biosorption percentage, for concentrations between $5 \mathrm{mg} \mathrm{l}^{-1}$ and $80 \mathrm{mg} \mathrm{l}^{-1}$, but it decreased sharply for Ni(II) concentrations higher than $80 \mathrm{mg} \mathrm{l}^{-1}$, reaching values lower than $45 \%$. There was a 30 fold increase in the uptake with the increase of the initial concentration, for values between $5 \mathrm{mg} \mathrm{l}^{-1}$ and $80 \mathrm{mg} \mathrm{l}^{-1}$. The saturation of the sorption sites occurs with the increasing concentration of $\mathrm{Ni}(\mathrm{II})$ and with the decreasing of active uptake by the bacteria, probably due to the inhibitory effect of the metal. This behavior was also observed by other authors (Kara and Kara, 2005; Chaudhuri et al., 2014).

The $\mathrm{pH}$ did not suffer significant variations, ranging from 7.09 $\mathrm{pH}$ to 6.89 , $\mathrm{f}$ or all the concentrations of $\mathrm{Ni}(\mathrm{II})$ tested. Since $\mathrm{Ni}(\mathrm{II})$ starts to precipitate in the form of $\mathrm{Ni}(\mathrm{OH})_{2}$ at $\mathrm{pH}$ of 7.6 , it is concluded that the decrease of $\mathrm{Ni}(\mathrm{II})$ concentration occurs by biological processes such as biosorption (Espinozo et al., 2012). These processes result from chemical bonds formed between the ion metal and functional groups present on the bacteria surface (phosphate, carbohydrate, amide I and amide II) (Costa et al., 2014).

The impact of Cd on the biofilm growth is presented in Fig. 1a. The duration of the lag phase is similar for the initial metal concentrations between $5 \mathrm{mg} \mathrm{l}^{-1}$ to $80 \mathrm{mg} \mathrm{l}^{-1}$, indicating that the bacterial culture needs the same time to endure intracellular changes in an effort to adapt itself to a new environment. The lag phase is significantly longer for $100 \mathrm{mg} \mathrm{l}^{-1}$ of $\mathrm{Cd}$, revealing that the bacterium needs more time to adapt to these hazardous conditions. Although the maximum concentration of biomass starts to decrease for initial concentrations of $\mathrm{Cd}$ higher than $5 \mathrm{mg} \mathrm{l}^{-1}$, the specific growth rate only decrease (about 25\%) for initial concentrations higher than $20 \mathrm{mg} \mathrm{l}^{-1}$. For comparison, Chaudhuri et al. (2014) investigated the adsorption of cadmium by Lemna minor and Spirodela polyrhiza and verified that the growth of half of those 
a)
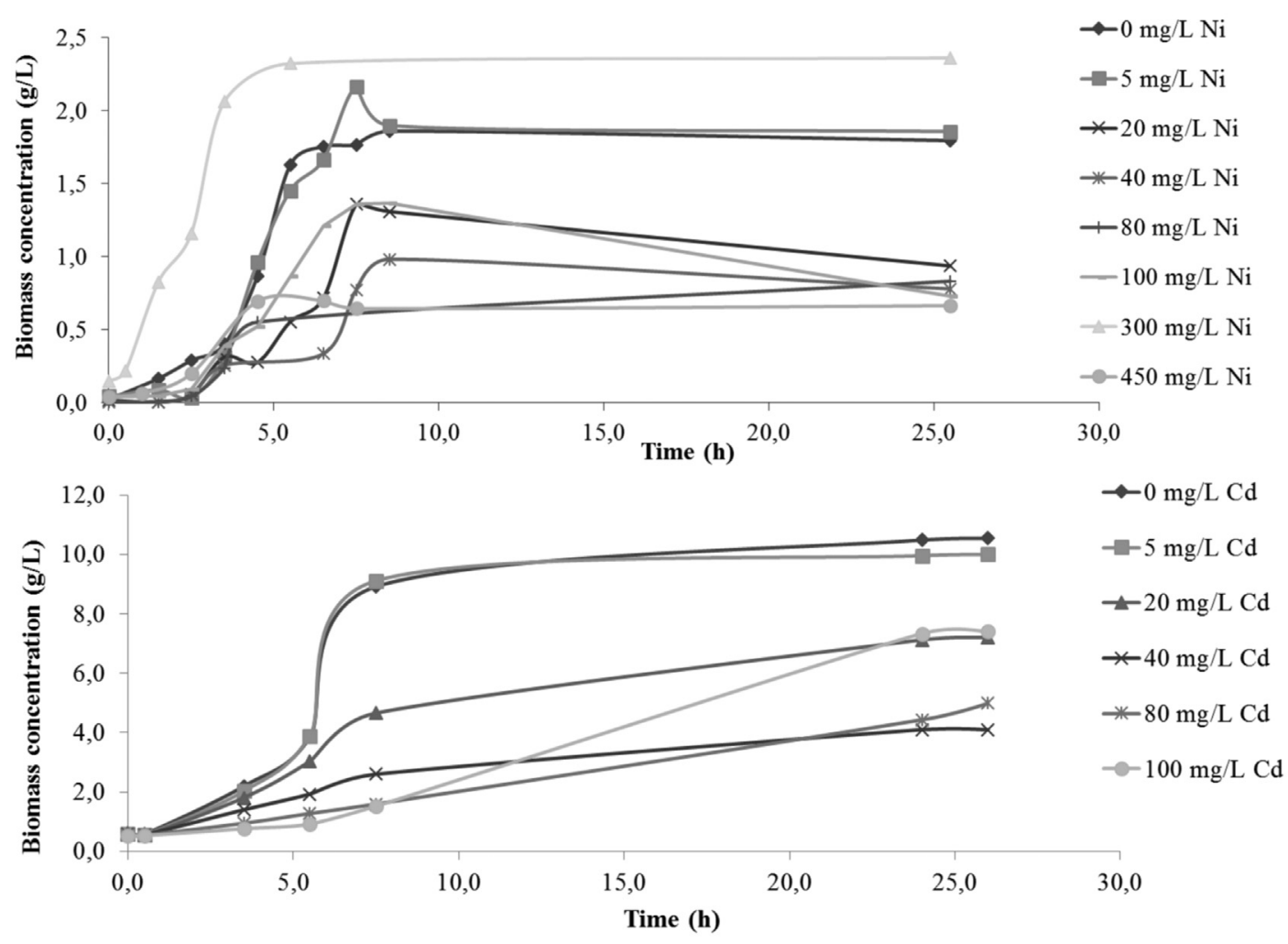

b)
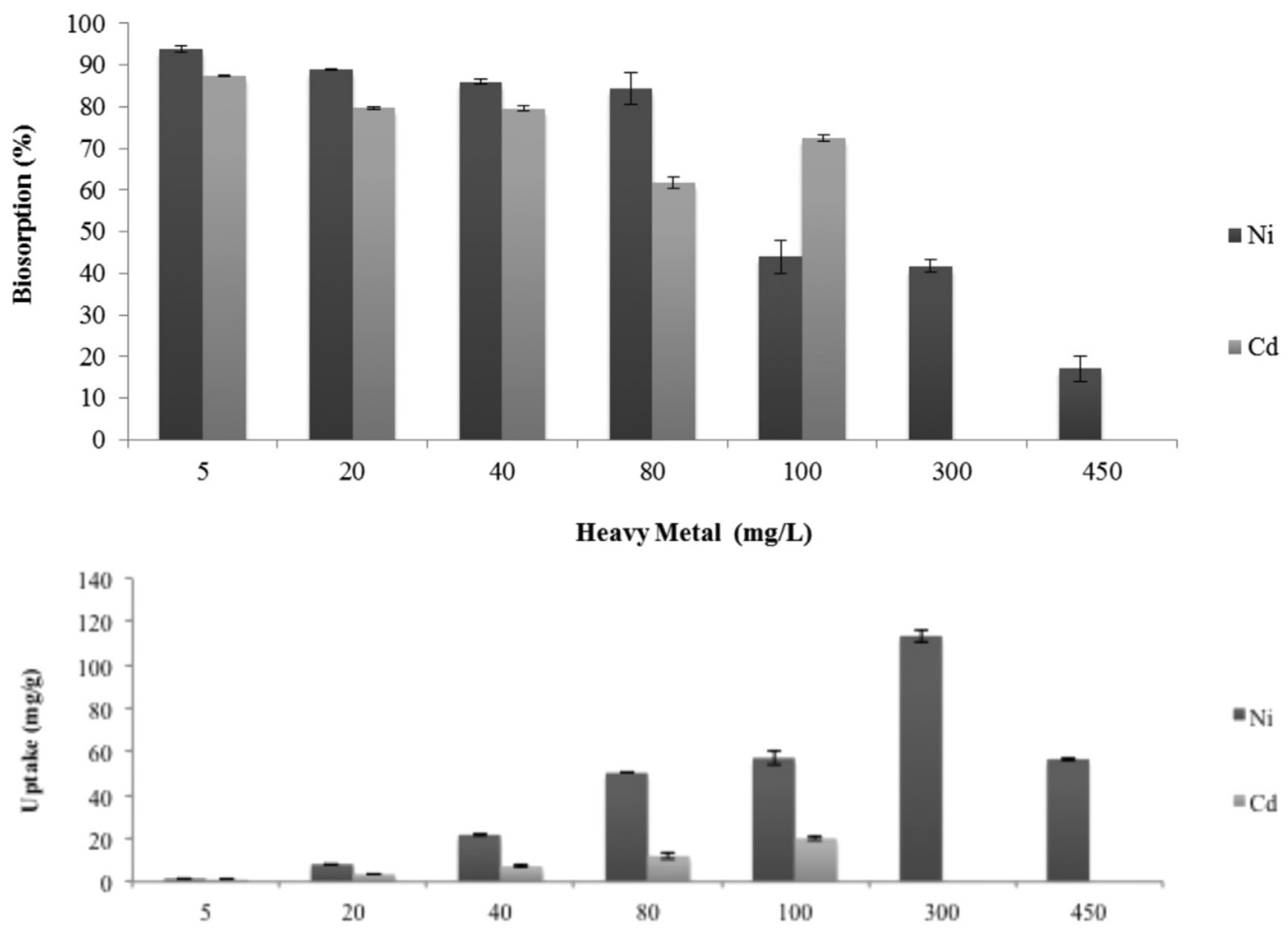

Heavy Metal $(\mathrm{mg} / \mathrm{L})$

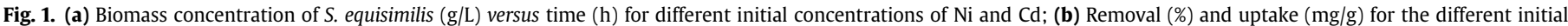
concentrations of $\mathrm{Ni}$ and $\mathrm{Cd}$. 
cultures was inhibited for concentrations higher than $0.89 \mathrm{mg} \mathrm{l}^{-1}$ and $1.46 \mathrm{mg} \mathrm{l}^{-1}$, respectively.

The suspended bacteria retained $87 \%, 80 \%, 80 \%, 62 \%$ and $73 \%$ of $\mathrm{Cd}$, when exposed to an initial cadmium concentration of $5 \mathrm{mg} \mathrm{l}^{-1}$, $20 \mathrm{mg} \mathrm{l}^{-1}, 40 \mathrm{mg} \mathrm{l}^{-1}, 80 \mathrm{mg} \mathrm{l}^{-1}$ and $100 \mathrm{mg} \mathrm{l}^{-1}$, respectively, Fig. $1 \mathrm{~b}$. Similar observations were reported by Kara and Kara (2005) and Chaudhuri et al. (2014) while removing cadmium from wastewater with different biomass cultures. Despite the sensitivity of the bacteria towards cadmium, the amount of initial cadmium retained was always higher than $60 \%$.

In these assays pH ranged from 6.05 to 6.98 . Since $\mathrm{Cd}(\mathrm{II})$ starts to precipitate as CdS for $\mathrm{pH}$ higher than 8 , the removal of $\mathrm{Cd}(\mathrm{II})$ is attributed to biological processes, such as biosorption and not to precipitation. The increase of $\mathrm{t} \mathrm{pH}$ results in an increase of the hydroxyl groups and other anionic functional groups. This makes the bacterial surface more negative, the number of electrostatic repulsions decreases and the number of electrostatic attraction increases, resulting in an increase of metal sorption (Badawy et al., 2010).

\subsubsection{Growth and biosorption kinetics modelling}

Since growth is the result of anabolic and catabolic enzymatic processes, the use of a substrate or cofactor in the microbial growth, as well as the production/removal of metabolites can be quantitatively described by growth kinetics models. The specific growth rate $(\mu)$ of a population of microorganisms can be related to the substrate concentration ( $S$ ) by a set of empirically derived rate laws. The growth and sorption kinetic modelling are presented in Table 1 and are discussed below. Monod and Powell models may be disregarded, as they do not take into consideration any inhibitory effect, which was verified to be exerted by both metals.

The value obtained for the coefficient of determination $\left(\mathrm{R}^{2}=0.872\right)$ showed that the experimental data is fairly described by the Luong model, and the high value obtained for K corroborates the inability of the Haldane model to properly describe the obtained data (Raghuvanshi and Babu, 2010). The coefficient of determination $\left(R^{2}=0.970\right)$ indicates that the Edwards model explains the microbial growth better than the Haldane and Luong counterparts. Although the kinetic parameters and the $\mathrm{R}^{2}$ values obtained with the Gompertz model $(>0.850)$ may suggest that this model can describe properly the experimental data, it does not comprise a parameter related with cellular maintenance. This is due to the fact that the substrate consumed for maintenance at the beginning of the experiments, when the biomass concentration is small, is practically negligible. However, it cannot be considered negligible with the course of the experiments (Fan et al., 2004). The existence of an inflection point makes sigmoid curves inappropriate for describing the exponential growth phase of microorganisms (Baty and Delignette-Muller, 2004).

The sorption kinetic model that best describes Ni sorption is the pseudo-second order $\left(R^{2}>0.915\right.$, Fig. $\left.2 a\right)$ meaning that under these experimental conditions the rate-limiting step for $\mathrm{Ni}$ sorption is dependent on the initial substrate concentration and on the concentration of biomass.

Cd toxicity assays allowed the determination of the growth kinetic parameters with the Haldane model $\left(\mu \mathrm{m}, \mathrm{K}_{\mathrm{S}}\right.$ and $\mathrm{K}_{1}$ ) were $0.44 \mathrm{~h}^{-1}, 0.84 \mathrm{~g} \mathrm{l}^{-1}$ and $36.44 \mathrm{~g} \mathrm{l}^{-1}$ (Table 1 ). The obtained values for the self-inhibition constant $\left(K_{1}\right)$, the substrate affinity constant $\left(K_{S}\right)$, associated with the coefficient of determination $\left(R^{2}=0.939\right)$ suggest that the culture under study is not very sensitive to substrate inhibition and that this model is able to describe the data properly. Although unexpected, the Luong model misfitting may be explained by the inexistence of lag phase and growth inhibition, due to the depletion of the substrate (Costa et al., 2012). The Edwards parameters, $\mu \mathrm{m}, \mathrm{K}_{\mathrm{S}}, \mathrm{K}_{1}$ and $\mathrm{K}$, were respectively $3.53 \mathrm{~h}^{-1}$, $16.25 \mathrm{~g} \mathrm{l}^{-1}, 10.69 \mathrm{~g} \mathrm{l}^{-1}$ and $6.75 \times 10^{21} \mathrm{mg} \mathrm{l}^{-1}$. The coefficient of determination $\left(\mathrm{R}^{2}=0.860\right)$ indicates that this model describes the microbial growth better than the Luong model. The Edwards model considers 1) the formation of toxic intermediates or by-products, 2) the changing activity of one or more enzymes, 3 ) the dissociation of one or more enzymes and 4) the formation of metabolic aggregates that can lead to the growth and substrate inhibition (Costa et al., 2012). Being more realistic, these assumptions explain the good fitting of this model. The kinetic parameters and the high value obtained for $\mathrm{R}^{2}(>0.950$ ) suggest that the Gompertz model might be able to fit the data properly. As previously mentioned, the inexistence of a maintenance parameter and the spotting of an inflection point, make the Gompertz model inappropriate to describe the exponential growth phase of microorganisms (Baty and DelignetteMuller, 2004).

The equation that best describes the sorption kinetics of Cd by the suspended bacteria for all the concentrations tested, is the pseudo second-order model $\left(\mathrm{R}^{2}>0.927\right.$, Fig. $\left.2 \mathrm{~b}\right)$. $\mathrm{K}_{2}$ constant decreases with the increase of cadmium concentration, indicating that the sorption rate of $\mathrm{Cd}$ decreases over time. Similar findings were reported by Çelekli and Bozkurt (2011) for the adsorption of $\mathrm{Cd}^{2+}$ on Spirulina platensis.

\subsection{Singular and binary sorption experiments}

\subsubsection{DEK sorption by vermiculite - process modelling}

The retention of DEK $\left(3 \mathrm{~g} \mathrm{l}^{-1}\right)$ by different masses of vermiculite $(0.085 \mathrm{~g}-40 \mathrm{~g})$, Fig. 3, showed similar profiles: initially it is rapid due to the high availability of surface adsorption sites, but it gradually becomes slower over time, due to the gradual occupation of those same sites. The results showed that as the mass of

Table 1

Monod, Powell, Haldane, Luong and Edwards growth kinetic parameters for S. equisimilis in the presence of Ni and Cd.

\begin{tabular}{|c|c|c|c|c|c|c|c|c|}
\hline Model & $\mu_{\max }\left(\mathrm{h}^{-1}\right)$ & $\mathrm{Ks}\left(\mathrm{g} \mathrm{l}^{-1}\right)$ & $\mathrm{K}_{1}\left(\mathrm{~g} \mathrm{l}^{-1}\right)$ & $\mathrm{K}\left(\mathrm{mg} \mathrm{l}^{-1}\right)$ & $\mathrm{S}_{\mathrm{m}}\left(\mathrm{g} \mathrm{l}^{-1}\right)$ & $\mathrm{m}$ & $\mathrm{n}$ & $\mathrm{R}^{2}$ \\
\hline \multicolumn{9}{|l|}{$\mathbf{N i}$} \\
\hline Monod & 0.83 & 0.52 & - & - & - & - & - & 0.514 \\
\hline Powell & 0.80 & 0.24 & - & - & - & $5.12 \times 10^{-5}$ & - & 0.493 \\
\hline Haldane & 0.89 & 0.88 & $-5.81 \times 10^{21}$ & - & - & - & - & 0.558 \\
\hline Luong & 1.81 & 12.04 & - & - & $5.00 \times 10^{15}$ & - & $1.42 \times 10^{13}$ & 0.872 \\
\hline Edwards & 0.78 & 0.17 & 492.20 & $1.41 \times 10^{15}$ & - & - & - & 0.970 \\
\hline \multicolumn{9}{|l|}{ Cd } \\
\hline Monod & 0.37 & -12.68 & - & - & - & - & - & 0.999 \\
\hline Powell & 0.38 & -13.08 & - & - & - & -0.04 & - & 0.999 \\
\hline Haldane & 0.44 & 0.84 & 36.44 & - & - & - & - & 0.939 \\
\hline Luong & 1.31 & 2.89 & - & - & $-2.97 \times 10^{16}$ & - & $-3.93 \times 10^{14}$ & 0.760 \\
\hline Edwards & 3.53 & 16.25 & 10.69 & $6.75 \times 10^{21}$ & - & - & - & 0.860 \\
\hline
\end{tabular}


a)

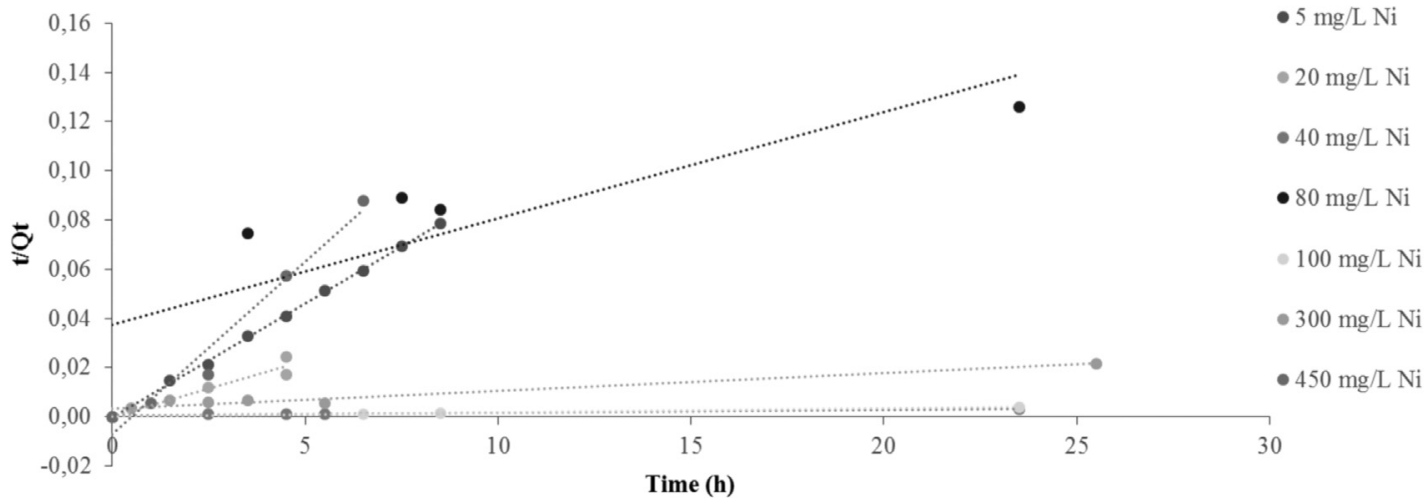

b)

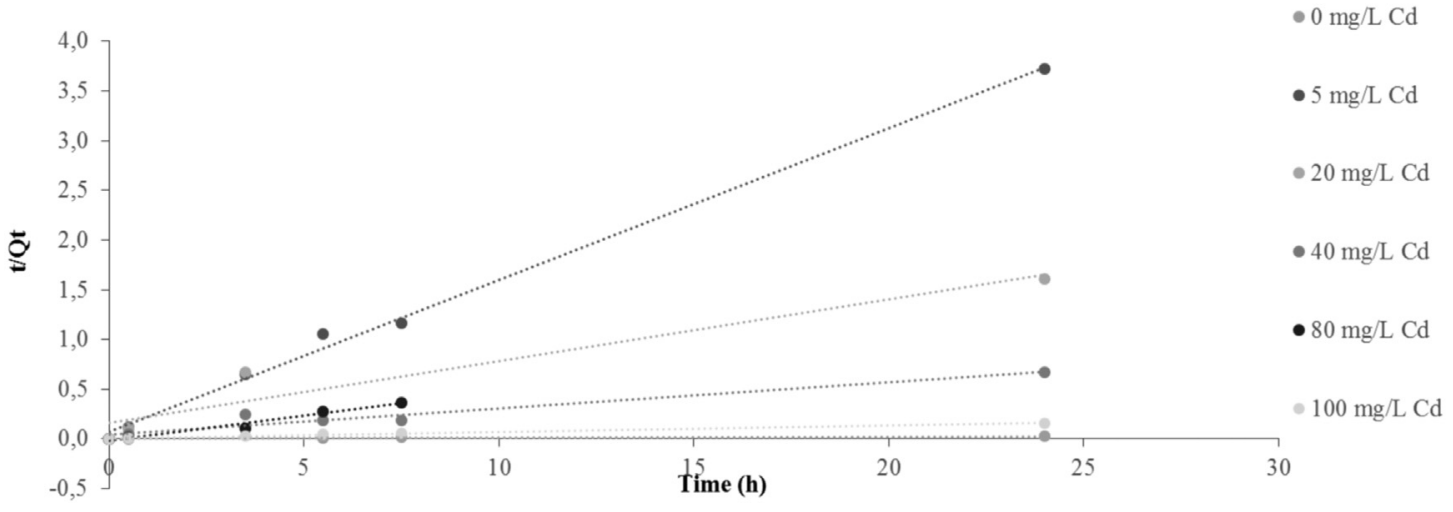

Fig. 2. Kinetics models for (a) Ni removal by S. equisimilis exposed to initial concentrations between $5 \mathrm{mg} / \mathrm{L}$ and $450 \mathrm{mg} / \mathrm{L}$; (b) Cd removal by S. equisimilis exposed to initial concentrations between $5 \mathrm{mg} / \mathrm{L}$ and $100 \mathrm{mg} / \mathrm{L}$.

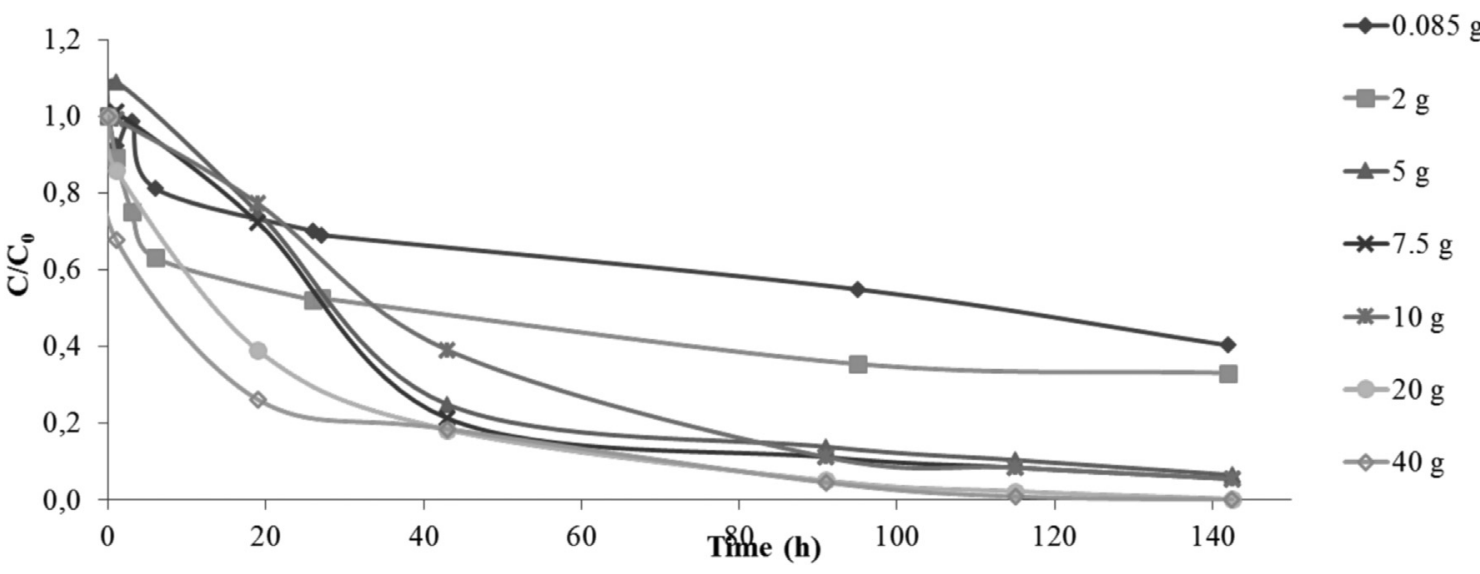

Fig. 3. Ratio between residual and initial concentration $(C / C O)$ of diethylketone versus time.

vermiculite increases, the percentage of DEK sorbed by the clay also increases, being almost complete for the assays conducted with $5 \mathrm{~g}$, $7.5 \mathrm{~g}$ and $10 \mathrm{~g}$ of vermiculite (sorption percentage higher than $92 \%$ ) and complete for vermiculite masses of $20 \mathrm{~g}$ and $40 \mathrm{~g}$, but the process itself is also 5 times faster. Several other authors also observed this behavior and explained it as a result of an increased surface area, which translates into a larger number of sites available for adsorption (Quintelas et al., 2011).

The experimental results are well described by the pseudosecond $\left(0.947 \leq \mathrm{R}^{2} \leq 0.999\right)$ and pseudo-first order $\left(0.913 \leq \mathrm{R}^{2} \leq 0.996\right)$ kinetic models. The $\mathrm{K}_{2}$ constant tends to increase with the increase of vermiculite dose, indicating that the sorption rate of DEK increases over time (Table 2), explained by the increased number of active sites available for sorption.

The relation between the pseudo-second order parameters and the adsorption performance was studied by several authors (Wu et al., 2009; Ofomaja, 2010), who established an approaching equilibrium factor (Rw) between the pseudo-second order constants and the characteristic kinetic curve. This approaching equilibrium factor is defined as:

$\mathrm{Rw}=1 /\left(1+\mathrm{K}_{2} \cdot \mathrm{q}_{\mathrm{e}} \cdot \mathrm{t}_{\mathrm{ref}}\right)$

In here $t_{\text {ref }}$ is the longest operation time (based on kinetic 
Table 2

Fitting parameters for pseudo-second order kinetic model for singular and binary sorption assays.

\begin{tabular}{llll}
\hline Single sorption assays & Vermiculite $(\mathrm{g})$ & \multicolumn{2}{l}{ Pseudo-second order } \\
\cline { 2 - 4 } & & $\mathrm{K}_{2}$ & $\mathrm{R}^{2}$ \\
\hline $\mathrm{DEK}$ & 0.085 & $5.00 \times 10^{-7}$ & 0.947 \\
& 2 & $8.18 \times 10^{-3}$ & 0.996 \\
& 5 & $8.85 \times 10^{-5}$ & 0.913 \\
& 7.5 & $1.36 \times 10^{-4}$ & 0.977 \\
& 10 & $2.81 \times 10^{-4}$ & 0.993 \\
& 20 & $2.06 \times 10^{-3}$ & 0.994 \\
$\mathrm{Ni}$ & 40 & $6.80 \times 10^{-3}$ & 0.996 \\
& 5 & $2.35 \times 10^{-1}$ & 0.999 \\
& 7.5 & $6.39 \times 10^{-2}$ & 0.998 \\
$\mathrm{Cd}$ & 20 & $6.05 \times 10^{-1}$ & 0.985 \\
& 40 & $8.59 \times 10^{-2}$ & 0.973 \\
& 5 & $5.12 \times 10^{-3}$ & 0.999 \\
& 7.5 & $4.26 \times 10^{-1}$ & 0.999 \\
& 20 & $2.46 \times 10^{-1}$ & 0.931 \\
& 40 & $5.88 \times 10^{-1}$ & 0.991 \\
\hline
\end{tabular}

experiments), qe and $\mathrm{K}_{2}$ correspond respectively to the equilibrium uptake and to the pseudo-second order constant. The Rw factor was found to range between 0.004 and 0.090 for all the vermiculite masses, with the exception of the assay conducted with $5 \mathrm{~g}$ of vermiculite $(\mathrm{Rw}=0.120)$. These results suggest that the kinetic curve is well approaching equilibrium, confirming the good performance of the system as established by Wu et al. (2009).

The equilibrium parameters for the adsorption of DEK onto vermiculite are listed in Table 3, along with the linear regression coefficients. The $\mathrm{R}^{2}$ values obtained for the BET and Freundlich isotherm models are close to unity, as opposed to the $\mathrm{R}^{2}$ value obtained for the Langmuir and D-R models. The BET parameter $\mathrm{C}_{S}$ indicates the saturation concentration of the solute $\left(C_{S}=0.43 \mathrm{mg} \mathrm{l}^{-1}\right)$ whereas the constant $B$ relates the energy of interaction with the surface $(B=0.76)$.

The energy of adsorption (ED) may be calculated by the following equation:

$\mathrm{E}_{\mathrm{D}}=1 / \sqrt{\left(2 \mathrm{~B}_{\mathrm{D}}\right)}$

Here, $B_{D}$ is an isotherm constant related to the mean free energy of adsorption per mole of adsorbate $\left(\mathrm{mol}^{2} \mathrm{~J}^{-2}\right)$. The obtained value of $E_{D}$ is lower than $8 \mathrm{~kJ} \mathrm{~mol}^{-1}$, suggesting that the adsorption process is physical in nature. Similar results were obtained by Ouadjenia-Marouf et al. (2013).

\subsubsection{Nickel sorption by vermiculite - process modelling}

Single sorption assays with $\mathrm{Ni}$ and vermiculite indicated that the sorption process is initially rapid due to the high availability of surface adsorption sites, but it becomes gradually slower through time, due to the gradual occupation of those same sites. It was found that despite the uptake decreases as the mass of vermiculite employed increases (from $24.69 \mathrm{mg} \mathrm{g}^{-1}$ to $4.78 \mathrm{mg} \mathrm{g}^{-1}$ ), the percentage of Ni sorbed increases, reaching a maximum value of $100 \%$ for vermiculite quantities higher than $7.5 \mathrm{~g}$, due to the increase of surface area available, which is translated into a higher number of active sites available for sorption.

Vermiculite can adsorb heavy metals by two distinct mechanisms: production of inner-sphere complexes through $\mathrm{Si}-\mathrm{O}^{-}$and $\mathrm{Al}-\mathrm{O}^{-}$groups at the vermiculite particle edges and cation exchange at the planar site. Since both mechanisms are $\mathrm{pH}$-dependent and $\mathrm{pH}$ changes the vermiculite surface properties and the metal speciation, it is concluded that $\mathrm{pH}$ plays an important and crucial role in the control of cationic adsorption from aqueous solutions (Badawy et al., 2010).

The $\mathrm{pH}$ ranged from 7.39 to 6.14 , while the vermiculite point of zero charge is 2 and $\mathrm{Ni}(\mathrm{II})$ precipitates in the form of $\mathrm{Ni}(\mathrm{OH})_{2}$ at a $\mathrm{pH}$ higher than 7.6. It may be concluded that the decrease on $\mathrm{Ni}(\mathrm{II})$ concentration is certainly due to sorption processes between $\mathrm{Ni}$ (II) and the functional groups $(\mathrm{Si}-\mathrm{O}-\mathrm{Si}, \mathrm{H}-\mathrm{O}-\mathrm{H}, \mathrm{CO}$ and $\mathrm{OH})$ present on the vermiculite surface (Espinozo et al., 2012).

The kinetic data are best described by the pseudo-second order model (Table 2). The behavior of the $\mathrm{K}_{2}$ constant was unexpected, since it decreased for assays with $5 \mathrm{~g}-7.5 \mathrm{~g}$ of vermiculite, and then increased for bigger vermiculite masses and decreases again, suggesting that the sorption rate oscillates through time and with the mass of sorbent employed (Plazinski et al., 2013).

The $\mathrm{R}_{\mathrm{w}}$ factor was found to range between 0.005 and 0.087 indicating that the kinetic curve is largely curved with a good approach to equilibrium, confirming the good performance of the system.

\subsubsection{Cadmium sorption by vermiculite - process modelling}

The single sorption assays with $\mathrm{Cd}$ revealed that the sorption process is initially rapid due to the high availability of surface adsorption sites, but it becomes gradually slower through time, due to the gradual occupation of those same sites. The percentage of sorbed $\mathrm{Cd}$ increases as the quantity of vermiculite increases, reaching a maximum value of $95 \%$ for vermiculite masses of $40 \mathrm{~g}$. $\mathrm{Cd}(\mathrm{II})$ precipitates at a $\mathrm{pH}$ higher than 8 and $\mathrm{pH}$ ranged from 7.23 to 5.78 in these experiments. This indicates that sorption processes

Table 3

Adsorption equilibria for different biosorption experiments.

\begin{tabular}{|c|c|c|c|c|c|c|}
\hline \multirow[t]{2}{*}{ Model } & \multirow[t]{2}{*}{ Parameter } & \multirow{2}{*}{$\frac{\text { Assay }}{\text { DEK }}$} & \multicolumn{2}{|l|}{ Assay } & \multicolumn{2}{|l|}{ Assay } \\
\hline & & & DEK & $\mathrm{Ni}$ & DEK & $\mathrm{Cd}$ \\
\hline \multirow[t]{4}{*}{ Langmuir } & $q_{\max }\left(\mathrm{mg} \mathrm{g}^{-1}\right)$ & 499.80 & 17,562 & $8.96 \times 10^{9}$ & 0.36 & 10.62 \\
\hline & $b\left(1 \mathrm{mg}^{-1}\right)$ & $1.57 \times 10^{-4}$ & $2.16 \times 10^{-4}$ & $2.77 \times 10^{7}$ & 9.97 & $4.87 \times 10^{-1}$ \\
\hline & $\mathrm{R}_{\mathrm{L}}$ & 0.81 & 0.17 & $4.03 \times 10^{-18}$ & $2.79 \times 10^{-4}$ & $1.39 \times 10^{-1}$ \\
\hline & $\mathrm{R}^{2}$ & 0.887 & 0.964 & 0.735 & 0.989 & 0.930 \\
\hline \multirow[t]{3}{*}{ Freundlich } & $K_{f}\left(\mathrm{mg} \mathrm{g}^{-1}\right)$ & $1.43 \times 10^{-1}$ & 160,409 & $1.05 \times 10^{-5}$ & 0.30 & $1.01 \times 10^{-6}$ \\
\hline & $n$ & 1.48 & 0.05 & 0.32 & 3.70 & $2.28 \times 10^{-1}$ \\
\hline & $\mathrm{R}^{2}$ & 0.896 & 0.999 & 0.995 & 0.979 & 0.994 \\
\hline \multirow[t]{3}{*}{ D-R } & $q_{D}\left(\mathrm{mg} \mathrm{g}^{-1}\right)$ & 0.09 & $1.31 \times 10^{-4}$ & 21.80 & 0.137 & 5.05 \\
\hline & $B_{D}\left(\mathrm{~mol}^{2} \mathrm{~J}^{-2}\right)$ & -0.03 & $-2.73 \times 10^{1}$ & $-3.08 \times 10^{-5}$ & -0.22 & $-6.10 \times 10^{-4}$ \\
\hline & $\mathrm{R}^{2}$ & 0.847 & 0.999 & 0.997 & 0.484 & 0.998 \\
\hline \multirow[t]{4}{*}{ BET } & $q_{\max }\left(\mathrm{mg} \mathrm{g}^{-1}\right)$ & -0.17 & 0.12 & $3.33 \times 10^{6}$ & 0.14 & 37.30 \\
\hline & $B$ & 0.76 & $-5.55 \times 10^{20}$ & $-3.01 \times 10^{22}$ & -1.96 & $6.51 \times 10^{14}$ \\
\hline & $C_{S}\left(\mathrm{mg} \mathrm{l}^{-1}\right)$ & 0.43 & -0.67 & $3.67 \times 10^{2}$ & -0.05 & $-1.77 \times 10^{16}$ \\
\hline & $\mathrm{R}^{2}$ & 0.999 & 0.999 & 0.998 & 0.999 & 0.956 \\
\hline
\end{tabular}


are responsible for the decrease of $\mathrm{Cd}(\mathrm{II})$ concentration through time, and precipitation processes may be discarded.

The pseudo-second order kinetic model describes properly the results achieved (Table 2 ). $K_{2}$ constant tends to increase as the mass of vermiculite employed increases and this is justified by the increased number of actives sites available for sorption. $\mathrm{R}_{\mathrm{w}}$ factor was found to range between 0.009 and 0.091 in these assays indicating that the kinetic curve is well approaching equilibrium, confirming the good performance of the system.

\subsubsection{Binary sorption experiments}

3.2.4.1. DEK and $\mathrm{Ni}$ sorption on vermiculite. The simultaneous adsorption of DEK and $\mathrm{Ni}$ showed that for all the quantities of vermiculite tested, a complete sorption of DEK was achieved within the first $8-24 \mathrm{~h}$, whereas for $\mathrm{Ni}$ as mass of vermiculite increased $\mathrm{Ni}$ sorption also increased, reaching a maximum of $100 \%$ and $99 \%$, respectively, for $7.5 \mathrm{~g}$ and $40 \mathrm{~g}$ of vermiculite within $8 \mathrm{~h}$ of experiment. According to Srivastava et al. (2006) a mixture of different adsorbates may exhibit three possible types of behavior: non-interaction, synergism or antagonism. Sorption of both sorbates is about 5 times faster when mixed than when in singular solutions, but the binary system also presents higher maximum sorption values, suggesting a synergetic effect between the two sorbates.

The $\mathrm{pH}$ was found to range between 7.24 and 6.26 indicating as before that the process responsible for the decrease of $\mathrm{Ni}(\mathrm{II})$ concentration is biosorption. Table 2 summarizes the sorption kinetics parameters and the linear regression coefficient $\left(R^{2}\right)$ obtained for the simultaneous sorption of DEK and $\mathrm{Ni}$ in batch systems. It is observable that sorption of both pollutants is best described by the pseudo-second order kinetic model $\left(0.978 \leq \mathrm{R}^{2} \leq 0.999\right.$ for DEK and $0.955 \leq \mathrm{R}^{2} \leq 0.998$ for Ni). Pseudo-second order constants $\mathrm{K}_{2}$ for DEK and for Ni tend to decrease as the mass of vermiculite increases, indicating that the sorption rate of DEK and Ni decreases over time, due to the saturation of the active sites available on the surface of the mineral clay and to the competition between these two pollutants for the same active sites. $R_{w}$ factor was found to range between 0.006 and 0.029 for DEK and between 0.034 and 0.095 for $\mathrm{Ni}$, indicating that the kinetic curve is largely curved with a good approach to equilibrium, endorsing the good performance of the system.

3.2.4.2. DEK and Cd sorption on vermiculite. DEK and Cd present different behaviors when mixed and exposed to different quantities of vermiculite. An increase on the mass of vermiculite leads to a decrease on the percentage of sorbed DEK (from $44 \%$ to $24 \%$ ) whereas the sorption percentage of $\mathrm{Cd}$ tends to increase, reaching a maximum value of $100 \%$ for $20 \mathrm{~g}$ and $40 \mathrm{~g}$ of vermiculite. Comparing with singular sorbate assays, an antagonistic behavior between these pollutants is established as sorption of DEK is negatively affected by the presence of $\mathrm{Cd}$. This is explained by the competition between both sorbates for the available sites on the surface of the clay and it is not due to $\mathrm{pH}$ variation since vermiculite point of zero charge is 2 and $\mathrm{Cd}(\mathrm{II})$ precipitates as sulfide at a $\mathrm{pH}$ higher than 8 .

Table 2 summarizes the kinetic parameters obtained for the pseudo-second order model, which best describes the experimental data for both pollutants. For both pollutants, the pseudosecond order constant $K_{2}$ increases with the increase of the mass of vermiculite suggesting that adsorption rate of DEK and Cd increases over time. Similar results were obtained by Vieira et al. (2010), Çelekli and Bozkurt (2011) and Chaudhuri et al. (2014). The $\mathrm{R}_{\mathrm{W}}$ factor was found to range between 0.004 and 0.167 for DEK and between 0.009 and 0.017 for $\mathrm{Cd}$, demonstrating the good performance of the system.

\subsection{Biosorption experiments}

In order to establish the most appropriate correlation between the concentration of adsorbate in the biosorbent phase and the concentration in aqueous solution several isotherm models were tested: Langmuir, Freundlich, Dubinin-Radushkevich (D-R) and BET. The mechanistic path of these processes may be deduced from kinetic modelling with equations such as zero-order, pseudo-first order and pseudo-second order.

\subsubsection{DEK and Ni biosorption}

Concentrated biomass of $S$. equisimilis (circa $5 \mathrm{~g} \mathrm{l}^{-1}$ ), diethylketone (3 $\left.\mathrm{mg} \mathrm{l}^{-1}\right), \mathrm{Ni}\left(450 \mathrm{mg} \mathrm{l^{-1 }}\right)$ and vermiculite $(0.085 \mathrm{~g}-40 \mathrm{~g})$ were used in the biosorption assays. The ratios between residual and initial concentration of DEK and of $\mathrm{Ni}\left(\mathrm{C} / \mathrm{C}_{0}\right)$ as functions of time are presented in Fig. 4a. As the mass of vermiculite increases, the $C / C_{0}$ ratio for DEK approaches 0 for all the assays, with the exception of the experiments with $0.085 \mathrm{~g}$ and $10 \mathrm{~g}$ of vermiculite. For $\mathrm{Ni}$, the $\mathrm{C} / \mathrm{C}_{0}$ ratio is slightly higher $(\sim 0.2)$, with the exception of the assay with $10 \mathrm{~g}$ of vermiculite, in which a sorption percentage of $98 \%$ was obtained (about 9 fold the results obtained for $0.085 \mathrm{~g}$ vermiculite). Fig. $4 \mathrm{~b}$ shows that the maximum sorption percentage of DEK does not increase significantly with the increase of the vermiculite mass. The maximum sorption percentage of DEK was obtained with $40 \mathrm{~g}$ of vermiculite, and is about 1.25 times the sorption percentage obtained with $7.5 \mathrm{~g}$ and $10 \mathrm{~g}$ (78\% and $80 \%)$. This may be related with the fact that 1) when the environmental conditions become unfavorable, the biofilm can act as clumps or as single colonies (Kesaano and Sims, 2014) and 2) the biofilm formed is composed by a single bacterial species. In general, a multiple species biofilm presents an enriched diversity and functionalities which are translated in an enhanced potential for degradation of toxic compounds (Burmølle et al., 2014).

In these experiments $\mathrm{pH}$ ranged between 5.66 and 6.20 and so precipitation can not be responsible for the decrease of $\mathrm{Ni}(\mathrm{II})$ concentration in solution (Espinozo et al., 2012). The increase of anionic groups in solution makes the surface of the biofilm negatively charged and the number of electrostatic attractions increase, resulting in an increase of metal sorption (Badawy et al., 2010). Table 4 shows that the uptake of both pollutants decreases as the sorbent mass (vermiculite and biomass) increases, probably due to saturation approaching. SEM observations demonstrated the presence of a biofilm of $S$. equisimilis on the support after exposure to an aqueous solution of DEK and Ni for $170 \mathrm{~h}$, validating the ability of this microorganism to grow in hazardous conditions, which is an advantage in treating contaminated wastewater. The adsorption kinetics for DEK and Ni are best fitted by the pseudo-second order model $\left(0.873<\mathrm{R}^{2} \leq 0.999\right.$ for DEK and $0.977<R^{2} \leq 0.999$, for Ni), Fig. 5a. The model assumes that the rate limiting step of the process is chemisorption (Quintelas et al., 2011), involving valence forces through the sharing or exchange of electrons between the biomass or the biomass mixed with mineral clay and DEK or $\mathrm{Ni}$, through complexation, coordination and/or chelation (Ahmady-Asbchin and Jafari, 2013). For DEK, the pseudo-second order $\mathrm{K}_{2}$ constant tends to decrease with the increase of the mass of vermiculite, suggesting that the sorption rate of DEK decreases over time. For $\mathrm{Ni}$, this constant tends to increase for vermiculite masses lower than $10 \mathrm{~g}$ and decreases for vermiculite masses higher than $7.5 \mathrm{~g}$. The biosorption rates of DEK and $\mathrm{Ni}$ are influenced by the mass of sorbate and by the microbial activity (biofilm growth, development and maturation), which can be translated into an increased need for nutrients and production of toxic metabolites. The Langmuir, Freundlich, BET and Dubinin-Radushkevich (D-R) models were 
$\mathbf{a}$

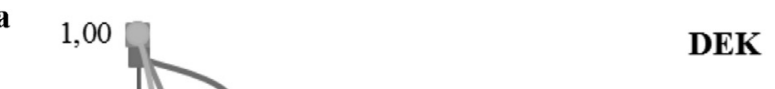

DEK

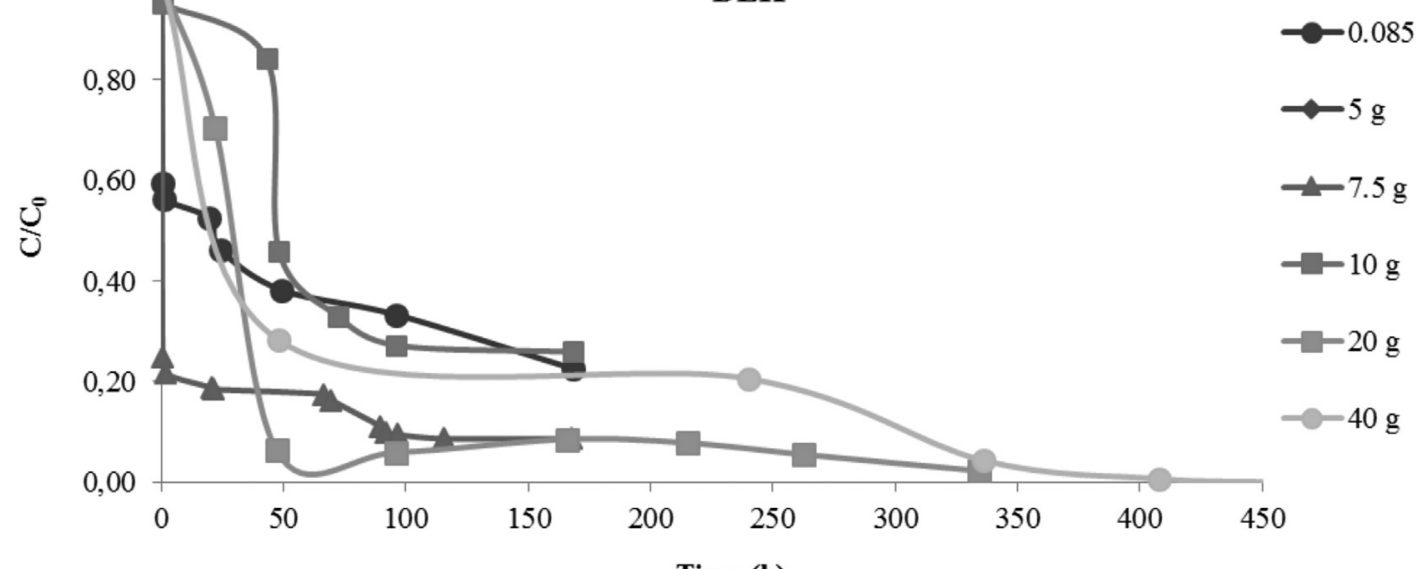

Time (h)

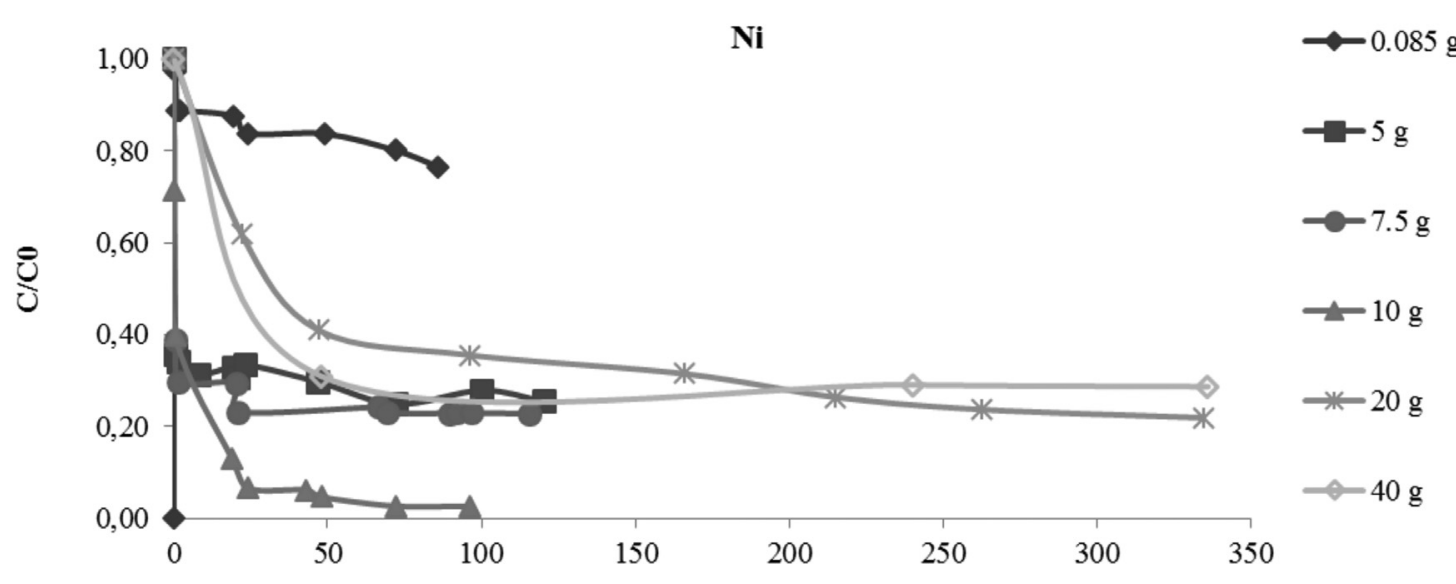

Time (h)

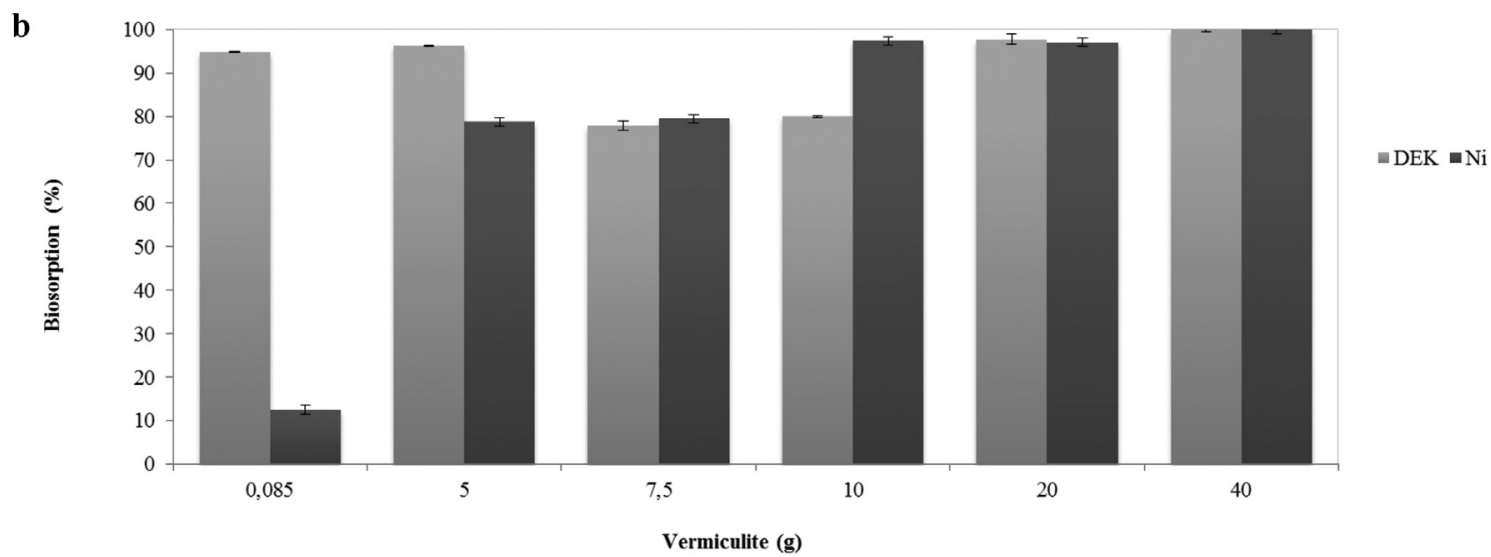

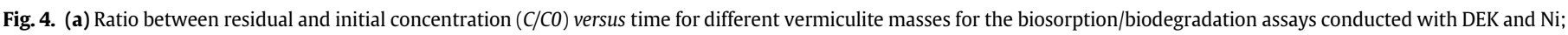
(b) Sorption percentage of DEK and Ni using a biofilm of $S$. equisimilis supported on different masses of vermiculite.

fitted to several experimental adsorption isotherms. Parameters are presented in Table 3 and the fitting is shown in Fig. 5b. The best fit for the biosorption of DEK was obtained with the Freundlich model $\left(R^{2}=0.999\right)$, suitable for heterogeneous surfaces with uniform energy distribution and reversible adsorption and suggesting that the adsorption energy decreases exponentially on saturation of the surface (Kishore et al., 2013). $K_{f}$ and $n$ were determined to be respectively $160,409 \mathrm{mg} \mathrm{g}^{-1}$ and 0.05 and indicate the high maximum adsorption capacity of the system and that the adsorption is favorable and cooperative $(1 / \mathrm{n}>1)$ (Dada et al., 2012). The values obtained for $\mathrm{q}_{\mathrm{D}}$ and $\mathrm{B}_{\mathrm{D}}$ of the Dubinin-Radushkevich model and the values obtained for $\mathrm{B}$ and $\mathrm{C}_{\mathrm{S}}$ with the BET model eliminate these equations from consideration.

$\mathrm{Ni}$ biosorption equilibrium of $\mathrm{Ni}$ is best fitted by the Freundlich isotherm. The values obtained for $\mathrm{K}_{\mathrm{f}}$ and $\mathrm{n}$ were respectively 
Table 4

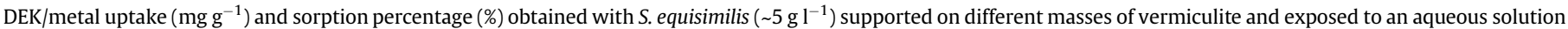
of DEK $\left(3 \mathrm{~g} \mathrm{l}^{-1}\right)$ and nickel/cadmium (100 $\left.\mathrm{mg} \mathrm{l}^{-1}\right)$ simultaneously.

\begin{tabular}{|c|c|c|c|c|}
\hline \multirow[t]{2}{*}{ Vermiculite (g) } & \multicolumn{2}{|l|}{$\mathrm{Ni}$} & \multicolumn{2}{|l|}{ DEK } \\
\hline & Uptake $\left(\mathrm{mg} \mathrm{g}^{-1}\right)$ & Sorption (\%) & Uptake $\left(\mathrm{mg} \mathrm{g}^{-1}\right)$ & Sorption (\%) \\
\hline 0.085 & 904.01 & 12.56 & 23470.00 & 94.80 \\
\hline 5 & 59.08 & 78.79 & 477.34 & 96.18 \\
\hline 7.5 & 40.08 & 79.50 & 191.20 & 77.90 \\
\hline 10 & 37.19 & 97.37 & 204.85 & 80.07 \\
\hline 20 & 14.76 & 97.04 & 125.04 & 97.73 \\
\hline 40 & 9.56 & 100.00 & 63.96 & 100 \\
\hline \multirow[t]{2}{*}{ Vermiculite (g) } & \multicolumn{2}{|l|}{$\mathrm{Ni}$} & \multicolumn{2}{|l|}{ DEK } \\
\hline & Uptake ( $\left.\mathrm{mg} \mathrm{g}^{-1}\right)$ & Sorption (\%) & Uptake (mg g $\left.{ }^{-1}\right)$ & Sorption (\%) \\
\hline 0.085 & 218.67 & 20.95 & 15678.96 & 42.38 \\
\hline 5 & 11.38 & 66.95 & 1843.58 & 49.73 \\
\hline 7.5 & 9.76 & 72.27 & 307.77 & 73.97 \\
\hline 10 & 7.26 & 85.37 & 214.73 & 94.32 \\
\hline 20 & 3.14 & 86.16 & 121.55 & 95.02 \\
\hline 40 & 2.10 & 98.85 & 63.67 & 99.53 \\
\hline
\end{tabular}

$1.05 \times 10^{-5} \mathrm{mg} \mathrm{g}^{-1}$ and 0.32 , indicating that the maximum sorption capacity of this system is lower for Ni than for DEK and that the sorption process is favorable and cooperative $(1 / \mathrm{n}>1)$.

\subsubsection{DEK and Cd biosorption}

Biosorption assays were carried out using a biofilm of S. equisimilis supported on vermiculite $(0.085 \mathrm{~g}-40 \mathrm{~g})$ and in contact with an aqueous solution of Cd $\left(100 \mathrm{mg} \mathrm{l}^{-1}\right)$ and DEK $\left(3 \mathrm{~g} \mathrm{l}^{-1}\right)$. The ratio between residual and initial concentration of DEK $\left(C / C_{0}\right)$ as a function of time is shown in Fig. 6a. Two distinct profiles were observed: for vermiculite masses larger than $0.085 \mathrm{~g}$ there is an initial and very fast phase, mainly controlled by the rapid surface saturation, followed by a second phase which depends mostly on the microorganism metabolism. For $0.085 \mathrm{~g}$ of vermiculite the sorption/biodegradation of DEK is not as notorious or fast, presenting only one phase.

The ratio between residual and initial concentration of $\mathrm{Cd}\left(\mathrm{C} / \mathrm{C}_{0}\right)$ as a function of time indicates that as the mass of vermiculite increases, the $\mathrm{Cd} \mathrm{C/CO}$ ratio decreases (Fig. 6a), reaching zero for the experiments conducted with $40 \mathrm{~g}$ of vermiculite. From Fig. 6a two distinct profiles were detected: for masses higher than $0.085 \mathrm{~g}$ of vermiculite, the sorption of $\mathrm{Cd}$ presents also two distinct phases: an initial and very fast phase mainly dominated by the rapid surface saturation, followed by a slower and metabolism dependent phase (Quintelas et al., 2012).

Table 4 shows that as the mass of the sorbent increases, the sorption percentage of DEK and Cd increases whereas their uptake decreases. This behavior was expected since the surface area available for the biofilm formation and for the retention of both pollutants also increases. Once again, the presence of a S. equisimilis biofilm on vermiculite, three hours after the start of the experiment and after $339.5 \mathrm{~h}$ was observed by SEM. These results corroborate, once again, the ability of this microorganism to grow in toxic conditions, which is an advantage in treating contaminated wastewater.

Experimental kinetic data for DEK and Cd is best described by the pseudo-second order model $\left(0.933<\mathrm{R}^{2} \leq 1\right.$ for DEK and $0.815<\mathrm{R}^{2} \leq 0.999$ for $\mathrm{Cd}$ ), Fig. 7a. For both pollutants, $\mathrm{K}_{2}$ constant increases for the assays conducted with $0.085 \mathrm{~g}-5 \mathrm{~g}$ of vermiculite and then it decreases for the assays conducted with $5 \mathrm{~g}-10 \mathrm{~g}$ of vermiculite, increasing again for the assays conducted with $10 \mathrm{~g}-40 \mathrm{~g}$ of vermiculite. These results indicate that the competition for the actives sites of the sorbent surface is generally dominated by DEK, most likely due to its transformation into other organic compounds that will compete with $\mathrm{Cd}$ for the active sites available and will be used as a carbon sources for the microorganism and, on the other hand, due to the toxicity of $\mathrm{Cd}$. In this set of experiments, the $\mathrm{R}_{\mathrm{w}}$ confirms the good performance of the system.

Langmuir, Freundlich, BET and D-R models were fitted to several experimental adsorption isotherms and the parameters are listed in Table 3, while the fitting quality of the different models is shown in Fig. 7b. The best fit for DEK was obtained with the Langmuir model $\left(R^{2}=0.989\right)$. This isotherm describes quantitatively the formation of a monolayer of adsorbate on the outer surface of the adsorbent, assuming that after that no additional adsorption occurs. The values obtained for $\mathrm{Q}_{\max }$, b and $\mathrm{R}_{\mathrm{L}}$ were respectively $0.36 \mathrm{mg} \mathrm{g}^{-1}$, $9.971 \mathrm{mg}^{-1}$ and $2.79 \times 10^{-4}$, and indicate that the sorption of DEK favorable $\left(0<R_{L}<1\right)$. For $C d$, the best fit was obtained with the Freundlich isotherm model $\left(\mathrm{R}^{2}=0.994\right)$. The values obtained for $\mathrm{K}_{\mathrm{f}}$ and $\mathrm{n}$ were respectively $1.01 \times 10^{-6} \mathrm{mg} \mathrm{g}^{-1}$ and $2.28 \times 10^{-1}$ showing the high adsorption capacity of the system and that the adsorption is favorable and cooperative $(1 / \mathrm{n}>1)$ (Dada et al., 2012).

\subsection{Identification of DEK degradation by-products}

During the biosorption experiments the sequential formation of several intermediates was detected. These metabolites were identified as 2-pentanone, methyl-acetate and ethyl-acetate and disappeared during the experiment, meaning that these same compounds were subject to biomass degradation/sorption. The detection and subsequent identification of the metabolites formed, allowed an approach to the metabolic degradation pathway of DEK by $S$. equisimilis, based on the classic metabolic degradation pathway of ketones, well described by Nielsen and Allard (2009) which takes place by carboxylation followed by hydrolysis:

$$
\mathrm{RCH}_{2} \mathrm{COCH}_{3} \longrightarrow \underset{\mathrm{CO}}{\mathrm{COHCOCH}_{3} \mathrm{H}} \longrightarrow \mathrm{RCH}_{2} \mathrm{CO}_{2} \mathrm{H}+\mathrm{CH}_{3} \mathrm{CO}_{2} \mathrm{H}
$$


$\mathbf{a}$
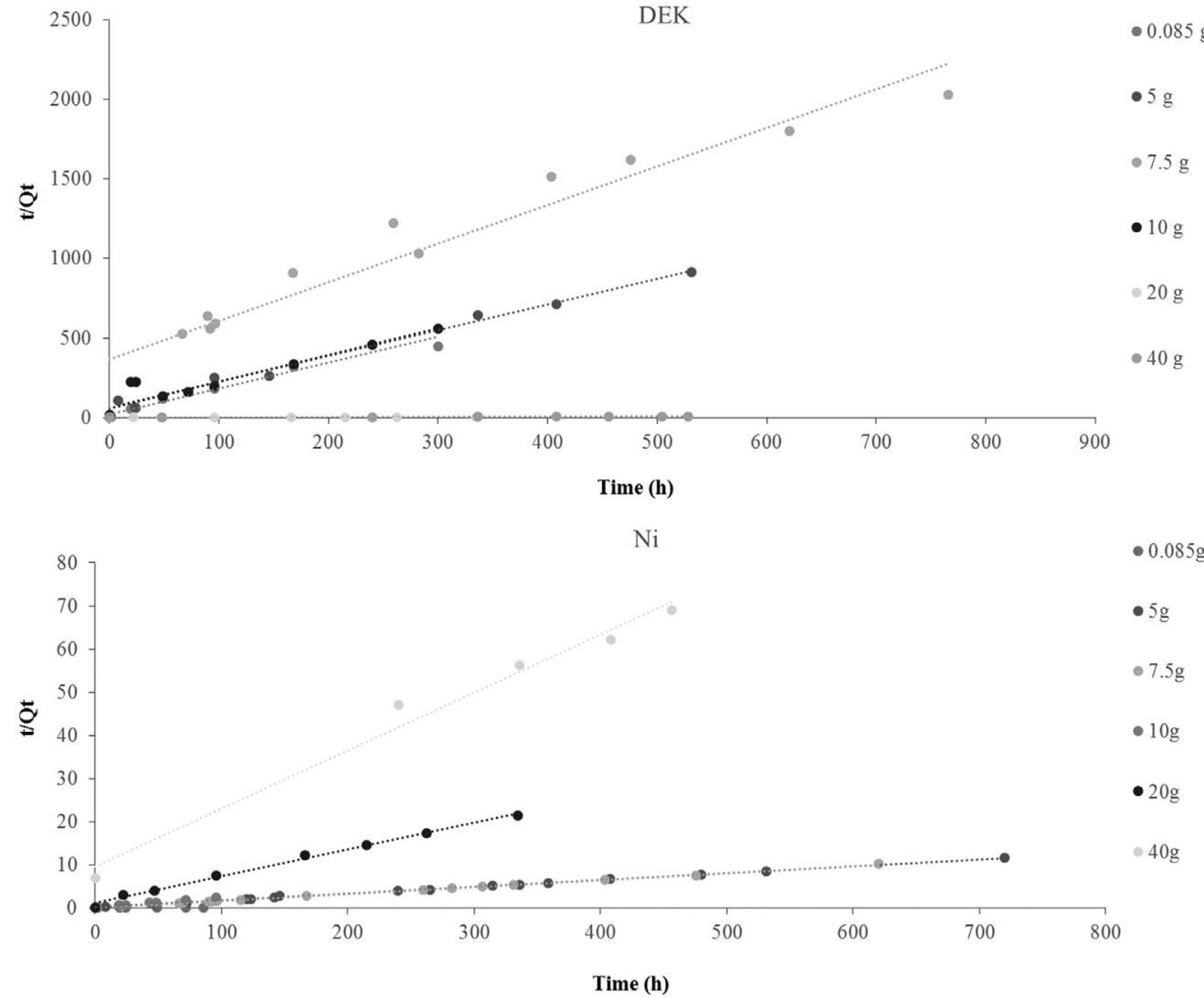

b

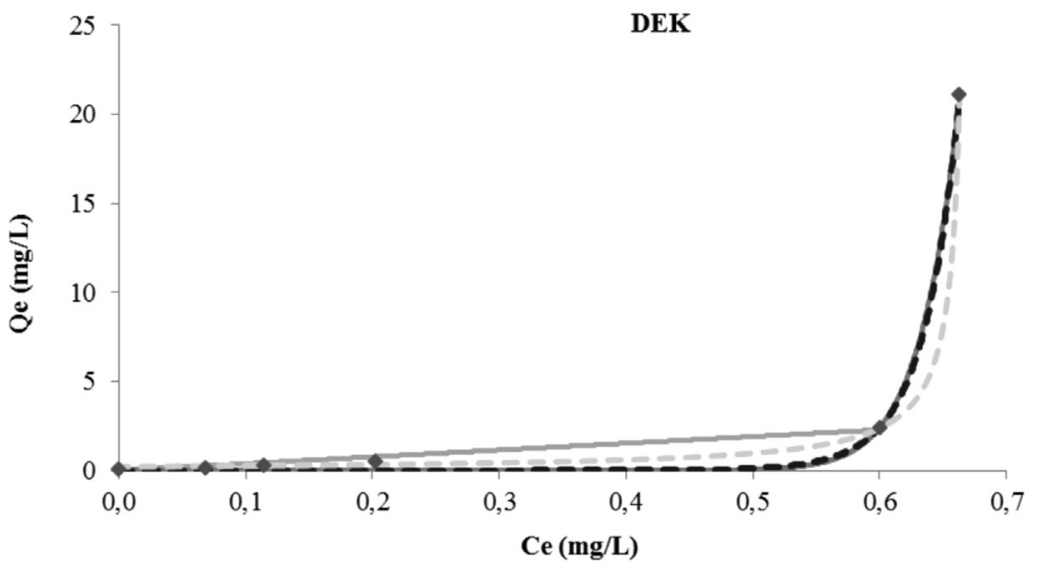

$\mathrm{Ni}$

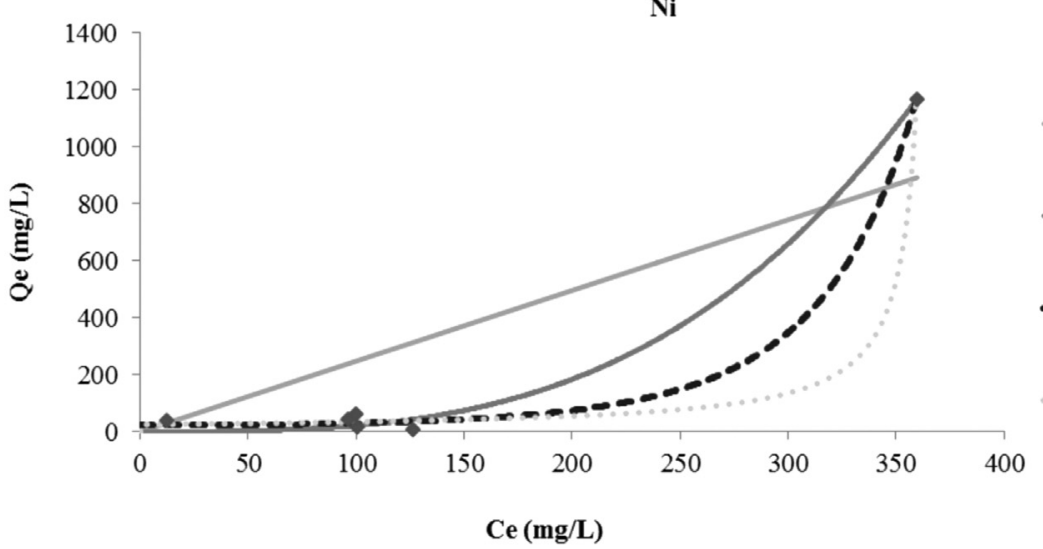

$\bullet 0.085 \mathrm{~g}$

- $5 \mathrm{~g}$

$\cdot 7.5 \mathrm{~g}$

- $10 \mathrm{~g}$

$\cdot 20 \mathrm{~g}$

- $40 \mathrm{~g}$
- Experimental data<smiles></smiles>

Freundlich

$---\mathrm{DB}$

$---\mathrm{BET}$

- Experimental data

Langmuir

- Freundlich

$---\mathrm{DB}$

BET

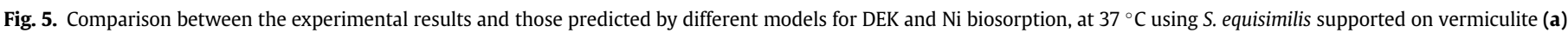
kinetics; (b) isothermic equilibria. 
a
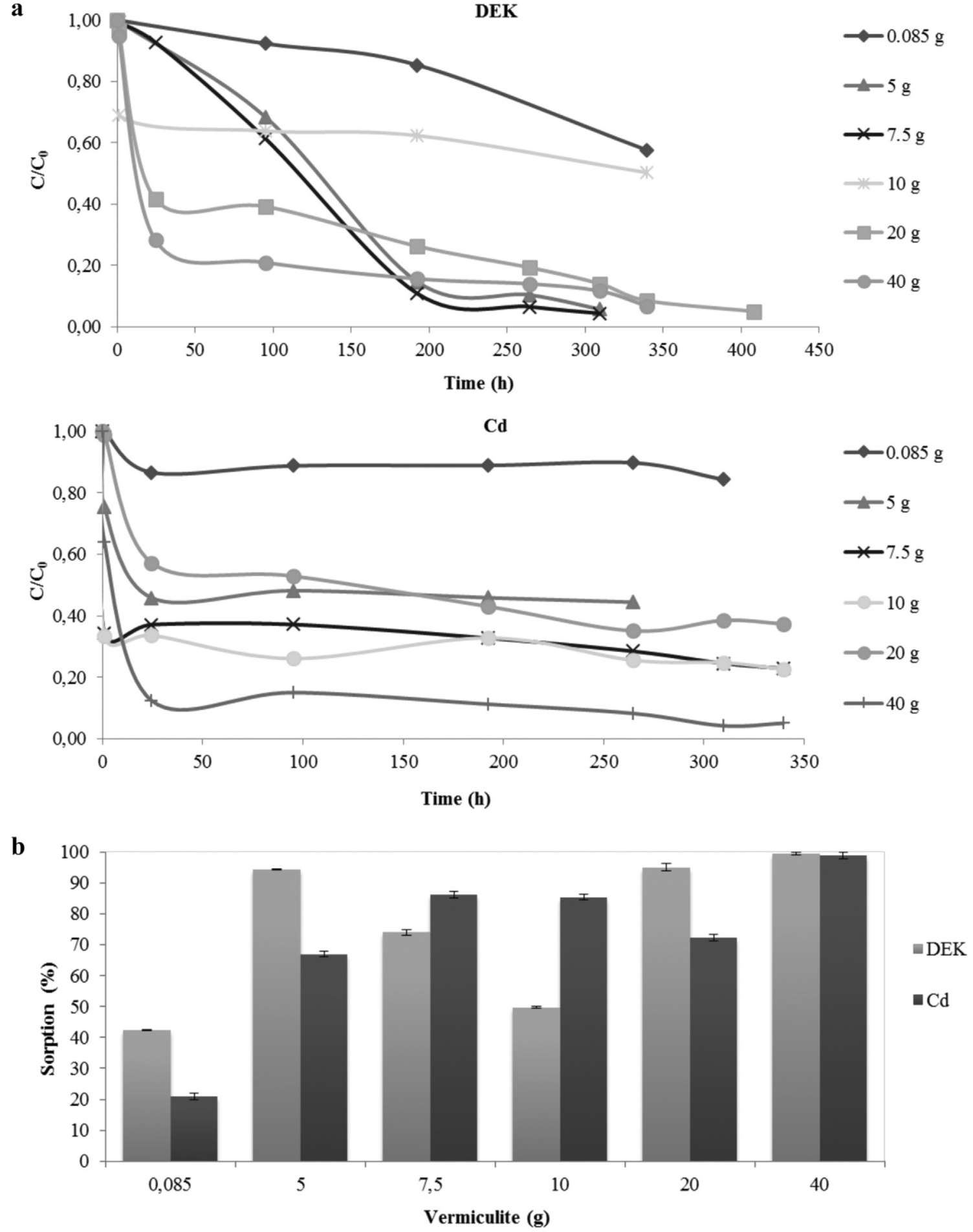

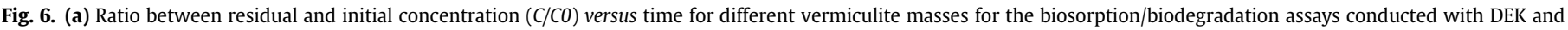
$\mathrm{Cd}$; (b) Sorption percentage of DEK and Cd using a biofilm of $S$. equisimilis supported on different masses of vermiculite.

Although the presence of 2-pentanone only represents a change on the carbon atom where the ketone group is attached to, the presence of compounds with lower number of carbons than DEK (methyl-acetate and ethyl-acetate) corroborate the existence of a biodegradation process. Based on the chronological detection of the by-products, DEK is firstly transformed in ethyl-acetate and posteriorly transformed in methyl-acetate. As mentioned above, all the metabolites are completely consumed by the biomass.

\section{Conclusions}

It was found that $S$. equisimilis is negatively affected by concentrations higher than $80 \mathrm{mg} \mathrm{l}^{-1}$ of $\mathrm{Ni}$ and $5 \mathrm{mg} \mathrm{l}^{-1}$ of $\mathrm{Cd}$ and that when vermiculite is able to efficiently sorb $\mathrm{Ni}$ and $\mathrm{Cd}$, by itself. A synergetic interaction between DEK and $\mathrm{Ni}$ is suggested in terms of adsorption by the clay, whereas when DEK and Cd are mixed, the sorption of DEK decreases significantly, revealing a negative effect 
a

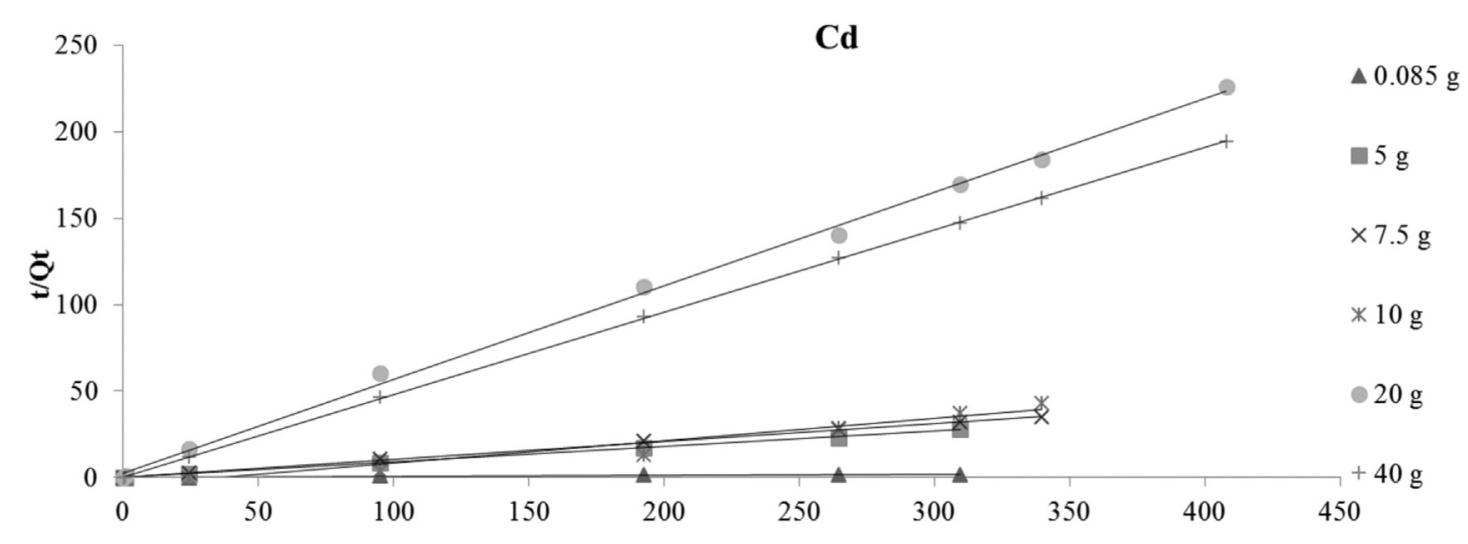

Time (h)

b

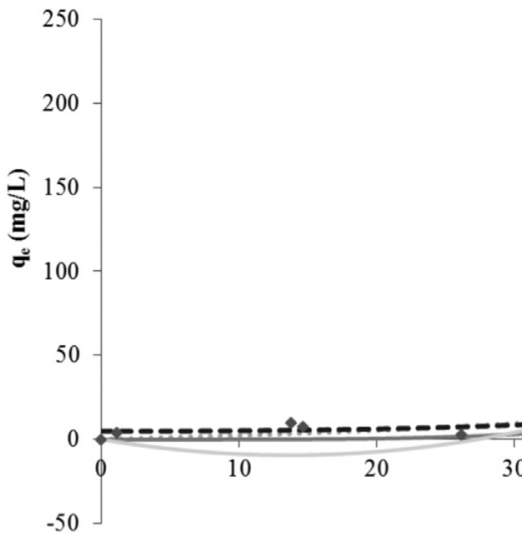

Cd

- Experimental data

Fig. 7. Comparison between the experimental results and those predicted by different models for DEK and Cd biosorption, at $37^{\circ} \mathrm{C}$ using S. equisimilis supported on vermiculite (a) kinetics; (b) isothermic equilibria.

of Cd over the retention of DEK The presence of the biofilm may be an advantage in this type of treatment, with a general increase in terms of sorption efficiency that can be explained by the functional surface groups on the biofilm, that may implement the substrate molecules adsorption and eventually promote the biodegradation of DEK, and by the increase of the available sites for sorption.

\section{Acknowledgments}

The authors would like to thank the Portuguese Foundation for Science and Technology (FCT) under the scope of the strategic funding of UID/BIO/04469/2013 unit and COMPETE 2020 (POCI-010145-FEDER-006684). Filomena Costa thanks FCT for a PhD grant (SFRH/BD/77666/2011).

\section{References}

Ahmady-Asbchin, S., Jafari, N., 2013. Removal of nickel and zinc from single and binary metal solutions by Sargassum angustifollium. Water Sci. Technol. 68, 1384-1390.

Ahmed, S., Chughtai, S., Keane, M.A., 1998. The removal of cadmium and lead from aqueous solution by ion exchange with Na-Y zeolites. Sep. Purif. Technol. 13, $57-64$

Andrews, J.F., 1968. A mathematical model for the continuous culture of microorganisms utilizing inhibitory substance. Biotechnol. Bioeng. 10, 707-723.

Araújo, M.M., Teixeira, J.A., 1997. Trivalent chromium sorption on alginate beads. Int. Biodeterior. Biodegrad. 40 (1), 63-74.

Badawy, N.A., El-Bayaa, A.A., Abd AlKhalik, E., 2010. Vermiculite as an exchanger fo
copper(II) and $\mathrm{Cr}$ (III) ions kinetic studies. Ionics 16, 733-739.

Baty, F., Delignette-Muller, M.-L., 2004. Estimating the bacterial lag time: which model, which precision? Int. J. Food Microbiol. 91, 261-277.

Burmølle, M., Ren, D., Djarnsholt, T., Sørensen, S.J., 2014. Interactions in multispecies biofilms: do they actually matter? Trends Microbiol. 22, 84-91.

Celekli, A., Bozkurt, H., 2011. Bio-sorption of cadmium and nickel ions using Spirulina platensis: kinetic and equilibrium studies. Desalination 275, 141-147.

Chaudhuri, D., Majumder, A., Misra, A.K., Bandyopadhyay, K., 2014. Cadmium removal by Lemna minor and Spirodela polyrhiza. Int. J. Phytoremediat. 16, $1119-1132$.

Chen, B.-Y., Utgikar, V.P., Harmon, S.M., Tabak, H.H., Bishop, D.F., Govind, R., 2000. Studies on biosorption of zinc(II) and copper(II) on Desulfovibrio desulfuricans. Int. Biodeterior. Biodegrad. 46 (1), 11-18.

Chopra, A.K., Pathak, C., 2010. Biosorption technology for removal of metallic pollutants - an overview. J. Appl. Nat. Sci. 2, 318-329.

Costa, F., Quintelas, C., Tavares, T., 2012. Kinetics of biodegradation of diethylketone by Arthrobacter viscosus. Biodegradation 23, 81-92.

Costa, F., Quintelas, C., Tavares, T., 2014. An approach to the metabolic degradation of diethylketone (DEK) by Streptococcus equisimilis: effect of DEK on the growth, biodegradation kinetics and efficiency. Ecol. Eng. 70, 183-188.

Dada, A.O., Olalekan, A.P., Olatunya, A.M., Dada, O., 2012. Langmuir, Freundlich, Temkin and Dubinin-Radushkevich isotherms studies of equilibrium sorption of $\mathrm{Zn}^{2+}$ unto phosphoric acid modified rice husk. IOSR J. Appl. Chem. 3, 38-45.

Dbson, R.S., Burgess, J.E., 2007. Biological treatment of precious metal refinery wastewater: a review. Miner. Eng. 20, 519-532.

Edwards, V.H., 1970. The influence of high substrate concentrations on microbial kinetics. Biotechnol. Bioeng. 12, 679-712.

Espinozo, E., Escudero, R., Tavera, f.j, 2012. Waste water treatment by precipitating copper, lead and nickel species. Res. J. Recent Sci. 1 (10), 1-6.

Fan, Y.Z., Wang, Y.Y., Qiao, P.-Y., Gu, J.-D., 2004. Optimization of phthalic acid batch biodegradation and the use of modified Richards model for modelling degradation. Int. Biodeterior. Biodegrad. 53, 57-63.

Hadi, P., Barford, J., McKay, G., 2013. Synergistic effect in the simultaneous removal 
of binary cobalt-nickel heavy metals from effluents by a novel e-waste-derived material. Chem. Eng. J. 228, 140-146.

Kara, Y., Kara, I., 2005. Removal of cadmium from water using duckweed (Lemna trisulca L.). Int. J. Agric. Biol. 7, 660-662.

Kesaano, M., Sims, R., 2014. Algae biofilm based technology or wastewater treatment. Algal Res. 5, 231-240.

Kishore, G., Sree, P., Krishna, D., 2013. Industrial wastes as adsorbents for the removal of chromium from waste water: a review. Int. J. Chem. Sci. 11, 1371-1384.

Kumar, R., Bhatia, D., Singh, R., Suman Rani, S., Bishnoi, N.R., 2011. Sorption of heavy metals from electroplating effluent using immobilized biomass Trichoderma viride in a continuous packed-bed column. Int. Biodeterior. Biodegrad. 65 (8), 1133-1139.

Kumar, R., Bhatia, D., Singh, R., Suman Rani, S., Bishnoi, N.R., 2012. Metal tolerance and sequestration of $\mathrm{Ni}(\mathrm{II}), \mathrm{Zn}(\mathrm{II})$ and $\mathrm{Cr}(\mathrm{VI})$ ions from simulated and electroplating wastewater in batch process: kinetics and equilibrium study. Int. Biodeterior. Biodegrad. 66 (1), 82-90.

Lam, K.-Y., Davidson, F.F., Hanson, R.K., 2012. High-temperature measurements of the reactions of $\mathrm{OH}$ with a series of ketones: acetone, 2-Butanone, 3-Pentanone, and 2-Pentanone. J. Phys. Chem. 116, 5549-5559.

Luong, J.H.T., 1987. Generalization of Monod kinetics for analysis of growth data with substrate inhibition. Biotechnol. Bioeng. 29, 242-248.

Marseaut, S., Debourg, A., Dostálek, P., Votruba, J., Kuncová, G., Tobin, J.M., 2004. A silica matrix biosorbent of cadmium. Int. Biodeterior. Biodegrad. 54 (2-3), 209-214.

Merrikhpour, H., Jalali, M., 2013. Sorption processes of natural Iranian bentonite exchanged with $\mathrm{Cd}^{2+}, \mathrm{Cu}^{2+}, \mathrm{Ni}^{2+}$, and $\mathrm{Pb}^{2+}$ cations. Chem. Eng. Commun. 200, 1645-1665.

Monod, J., 1949. The growth of bacterial cultures. Annu. Rev. Microbiol. 3, 371-394.

Montagnolli, R.N., Lopes, P.R.M., Bidoia, E.D., 2009. Applied models to biodegradation kinetics of lubricant and vegetable oils in wastewater. Int. Biodeterior. Biodegrad. 63, 297-305.

Morlett-Chávez, J.A., Ascacio-Martínez, J.A., Rivas-Estilla, A.M., VelásquezVadillo, J.F., Haskins, W.E., Barrera-Saldaña, H.A., Acuña-Askar, K., 2010. Kinetics of BTEX biodegradation by a microbial consortium acclimatized to unleaded gasoline and bacterial strains isolated from it. Int. Biodeterior. Biodegrad. 64, 581-587.

Nielsen, A., Allard, A.S., 2009. Chemistry of organic pollutants. In: Sabljic, A. (Ed.), Environmental and Ecological Chemistry, vol. 1. Eolss, ISBN 978-1-84826-186-0, pp. 1-424 (eBook).

Ofomaja, A.E., 2010. Biosorption studies of Cu (II) onto Mansonia sawdust: process design to minimize biosorbent dose and contact time. React. Funct. Polym. 70, 879-889.

Ouadjenia-Marouf, F., Marouf, R., Schott, J., Yahiaoui, A., 2013. Removal of Cu(II), $\mathrm{Cd}(\mathrm{II})$ and $\mathrm{Cr}(\mathrm{II})$ ions from aqueous solution by dam silt. Arab. J. Chem. 6, 401-406.

Plazinski, W., Dziuba, J., Rudzinski, W., 2013. Modeling of sorption kinetics: the pseudo-second order equation and the sorbate intraparticle diffusivity. Adsorption 19, 1055-1064.

Powell, E.O., 1967. The Growth Rate of Microorganisms as Function of Substrate Concentration. E. C.G.T., S. R.E. HMSO, London, United Kigndom.
Qin, B., Luo, H., Liu, G., Zhang, R., Chen, S., Hou, Y., Luo, Y., 2012. Nickel ion removal from wastewater using the microbial electrolysis cell. Bioresour. Technol. 121, 458-461.

Quintelas, C., Costa, F., Tavares, T., 2012. Bioremoval of diethylketone by the synergistic combination of microorganisms and clays: uptake, removal and kinetic studies. Environ. Sci. Pollut. Res. 20, 1374-1383.

Quintelas, C., Figueiredo, H., Tavares, T., 2011. The effect of clay treatment on remediation of diethylketone contaminated wastewater: uptake, equilibrium and kinetic studies. J. Hazard. Mater. 186, 1241-1248.

Raghuvanshi, S., Babu, B.V., 2010. Biodegradation kinetics of methyl iso-butyl ketone by acclimated mixed culture. Biodegradation 21, 31-42.

Sahoo, N.K., Pakshirajan, K., Ghosh, P.K., 2010. Enhancing the biodegradation of 4 chlorophenol by Arthrobacter chlorophenolicus A6 via medium development. Int. Biodeterior. Biodegrad. 64, 474-480.

Sar, P., Kazy, S.K., Asthana, R.K., Singh, S.P., 1999. Metal adsorption and desorption by lyophilized Pseudomonas aeruginosa. Int. Biodeterior. Biodegrad. 44 (2-3), $101-110$.

Sar, P., Kazy, S.K., Souza, S.F.D., 2004. Radionuclide remediation using a bacterial biosorbent. Int. Biodeterior. Biodegrad. 54 (2-3), 193-202.

Saravanan, P., Pakshirajan, K., Saha, P., 2009. Batch growth kinetics of an indigenous mixed microbial culture utilizing $\mathrm{m}$-cresol as the sole carbon source. J. Hazard. Mater. 162, 476-481.

Srivastava, V.M., Mall, I.D., Mishra, I.M., 2006. Equilibrium modelling of single and binary adsorption of cadmium and nickel onto bagasse fly ash. Chem. Eng. J. 117, 79-91.

Suazo-Madrid, A., Morales-Barrera, L., Aranda-Garcia, E., Cristiani-Urbina, E., 2011. Nickel (II) biosorption by Rhodotorula glutinis. J. Ind. Microbiol. Biotechnol. 38, $51-64$.

Vieira, M.G.A., Neto, A.F.A., Gimenes, M.L., Silva, M.G.C., 2010. Sorption of kinetics and equilibrium for the removal of nickel ions from aqueous phase on calcined Bofe bentonite clay. J. Hazard. Mater. 177, 362-371.

Volesky, B., 1990. Biosorption of Heavy Metals. CRC press, Boca Raton, Florida.

Wang, Y.L., Gu, J.D., 2005. Influence of temperature, salinity and pH on the growth of environmental isolates of Aeromonas and Vibrio species isolated from Mai Po and the Inner Deep Bay Nature Reserve Ramsar site of Hong Kong. J. Basic Microbiol. 45, 83-93.

Wu, F.-C., Tseng, R.-L., Huang, S.-C., Juang, R.-S., 2009. Characteristics of pseudosecond-order kinetic model for liquid-phase adsorption: a mini-review. Chem. Eng. J. 151, 1-9.

Yin, Y., Hu, Y., Xiong, F., 2011. Sorption of Cu(II) and Cd(II) by extracellular polymeric substances (EPS) from Aspergillus fumigates. Int. Biodeterior. Biodegrad. 65 (7), 1012-1018.

Zwietering, M.H., Jongenburger, I., Rombouts, F.M., Van't Riet, K., 1990. Modeling of the bacterial growth curve. Appl. Environ. Microbiol. 56, 1875-1881.

\section{Web}

https://pubchem.ncbi.nlm.nih.gov/compound/7288 (last access: 19/07/2016).

https://toxnet.nlm.nih.gov/cgi-bin/sis/search2/f?./temp/ 26jxaB:3 (last access: 19/ 07/2016) 